\title{
POLIITIKOT JULKKIKSINA
}

\section{HUOMIOITA VIIHTEELLISTYVÄSTÄ POLIITIKKOJULKISUUDESTA}

\begin{abstract}
Artikkelissa tarkastellaan viime vuosina Suomessa ja muuallakin maailmassa yleistynyttä poliitikkojen yksityisasioiden viihteellistä käsittelyä mediassa. Politiikka on henkilöitynyt ja "julkkistunut", jonka seurauksena poliitikot esitetään mediassa samaan tapaan kuin viibdejulkkikset. Medialla on merkittävää agendavaltaa nostaa poliitikkojen intiimit asiat tärkeimmiksi keskustelun aibeiksi ja buomion kohteiksi ybteiskunnassa. Artikkelissa kysytä̈n, onko tällainen julkisuus triviaalia, kansalaisuutta ja demokratiaa heikentävää, vai päinvastoin demokratiaa vahvistavaa? Vanhempi, "moderni" tutkimustraditio subtautuu ilmiöön kielteisesti ja uudempi, "postmoderni" traditio myönteisesti. Artikkelissa analysoidaan näitä molempia lähestymistapoja. Uudempi näkökulma nähdään vanhemman antiteesiksi ja sellaisena liian yksipuoliseksi. Artikkelissa luodaan aluksi kokonaiskuva poliitikkojen julkkistumisesta kontekstualisoimalla se historiallisesti ja kansainvälisesti, selvittämällä median ja politiikan subteen muutoksia sekä arvioimalla kulttuurin postmodernisoitumista. Poliitikkojen julkkistumista käsitteellistetään keskustelemalla journalismin viibteellistymisestä ja populaarikulttuuristumisesta. Julkkistumista voidaan pitää journalismin "populaarikulttuuristumisen" ybtenä muotona. Tutkimuksessa tarkastellaan ilmiötä sekä journalismin että politiikan näkökulmat buomioon ottaen.
\end{abstract}

Viime vuosina suomalaisesta politiikasta ja poliitikoista on syntynyt mediajulkisuudessa viihteellinen yleisvaikutelma ennen muuta siksi, että iltapäivälehdistö lööppeineen on toistuvasti herkutellut johtavien poliitikkojen yksityiselämää koskevilla kohuilla. Myös "vakavampi" media on ottanut osaa kohu-uutisointiin. Poliitikkoja on kohdeltu median näyttämöllä paljolti samaan tapaan kuin viihdejulkkiksia. Vaikuttaa siltä, että poliitikoista on tehty viihdettä, joko heidän suostumuksellaan tai ilman sitä.

Tässä artikkelissa pyritään lisäämään ymmärrystä poliitikkojen yksityiselämää koskevasta kohujulkisuudesta, erityisesti sen viihteellistyvästä 
tai populaarikulttuuristuvasta luonteesta. ${ }^{1}$ Artikkelin alkuosassa kuvataan politiikan ja median suhteita sekä politiikan esittämistapaa mediassa yhteiskuntahistoriallisessa kontekstissaan. Artikkelin loppupuolella pohditaan, miten viihteellistymistä on käsitteellistetty ja kysytään, onko viihteellistyminen demokratian kannalta myönteinen vai kielteinen asia.

Esimerkkeinä tarkasteltavasta ilmiöstä suomalaisessa kontekstissa mainittakoon pääministeri Matti Vanhasen, ministeri Tanja Karpelan, ministeri Ilkka Kanervan sekä puoluesihteeri Harri Jaskarin tapaukset. Esimerkiksi keväällä 2006 lööpeissä kerrottiin kuinka "Vanhasella on haku päällä", ja kuinka hän lähettelee "lemmekkäitä" viestejä naisille. Karpelan romanssit ovat olleet tarkan mediaseurannan alaisia. Erityisesti näin tapahtui "Suomen kuningasparin", Karpelan ja ministeri Sauli Niinistön parisuhteen aikana vuosina 2001-2004. Ilkka Kanerva joutui eroamaan mittavan mediakohun saattelemana keväällä 2008, koska hänen katsottiin lähettäneen sopimattomia tekstiviestejä eroottiselle tanssijattarelle. Jaskarin puolestaan väitettiin syyllistyneen virolaisen tyttöystävänsä paritukseen syksyllä 2006. Tapaus myös johti poliisitutkintaan. Iltapäivälehdet saivat aiheen herkutella etusivuillaan "puoluepomon seksiskandaalilla". Jaskari joutui jättämään tehtävänsä, vaikka poliisi ei myöhemmin löytänytkään katetta rikossyytteille. ${ }^{2}$

Tapauksissa on kyse poliitikkojen yksityiselämään liittyvistä skandaaleista, joita käsiteltiin uutisissa viikkoja ${ }^{3}$. Myös perinteisen asiajournalismin tai niin sanotun laatumedian edustajat herkuttelivat aiheilla iltapäivälehtien tapaan. Aikaisemmin "tärkeät uutiset" ja "hömppä"4 sijoittuivat journalistisessa tuotteessa selkeästi eri osastoille, yleensä siten, että tärkeät asiat olivat etusivulla tai ykkösuutisina. Nyt näyttää siltä, että hömppä on noussut uutisarvostuksissa kärkeen, mikä on perinteisen journalismin kriteerein mitattuna arveluttavaa ${ }^{5}$. On huolestuttu median tabloidisoitumisesta ja sensationalisoitumisesta. Asiapainotteisessa journalismissa ei ole ollut tapana nostaa etusijalle jonkun viihdejulkkiksen yksityiselämää, mutta huippupoliitikon kohdalla näin on voitu tehdä. Journalistit ovat voineet perustella toimensa vallan vahtimisen tehtävällään: korkean poliitikon kaikki tekemiset kuuluvat julkisen tarkkailun piiriin. Tätä kautta asiajournalismikin saa oikeutuksen tirkistellä poliitikon yksityiselämää. Tavallisen kansalaisen tirkistelyn kieltäisi laki ja journalistietiikka, mutta korkean päättäjän rajoittunut yksityisyydensuoja mahdollistaa poliitikon intiimielämän julkisen käsittelyn ${ }^{6}$.

Journalismi on joukko sovittuja käytäntöjä, joiden on vaikea pysyä ennallaan, kun muu yhteiskunta, talous ja mediakenttä ovat jatkuvassa mullistuksessa (Wiio 2006; Olkinuora 2006; Pietilä 2007). Eronteko yksityisiin ja julkisiin asioihin on yhteiskunnallinen konventio, joka voi muuttua. Viihteen ja uutisten erillään pitäminen on sekin eräänlainen sopimus, jota voidaan muuttaa. Media ei välttämättä kysy lupaa kohun keskelle joutuneilta henkilöiltä tai edes yleisöltä, kun sen on kilpailussa selviytyäkseen muutettava käytäntöjään.

Journalismin irtautuminen perinteisistä rajoituksista voidaan nähdä populaarikulttuurin ja viihteen tulona journalismiin, toisin sanoen journalismin populaarikulttuuristumisena. Barry Richards $(2004,340)$ toteaa, että ihmisten suhtautuminen politiikkaan on muuttunut populaarikult- 
tuurin kuluttamisen kaltaiseksi: "Populaarikulttuurin kokemistamme luonnehtivat sitoutumisen ja arvostelukyvyn muodot ovat yhä enemmän käytössä myös politiikan kokemuksissamme". Journalismin populaarikulttuurisuus nostettiin tosin esiin jo Peter Dahlgrenin ja Colin Sparksin 1990luvun alussa toimittamassa kirjassa Journalism and Popular Culture (Dahlgren \& Sparks 1992). Dahlgren (1992, 7) huomauttaa, että "kovat uutiset" muodostavat lopulta vain vähäisen osan nykyajan journalismista. Muu journalismi onkin jo lähempänä populaarikulttuuria, esimerkiksi tabloidit (popular press) ovat luontevasti osa sitä. Lisäksi journalismia ja laajempaa populaarikulttuurin aluetta yhdistää teoksen mukaan muun muassa tarinankerronta. Näistä lähtökohdista Dahlgren ja Sparks kumppaneineen puolustavat populaarijournalismia ja kritisoivat "elitististä" laatujournalismia. Tämä kulttuurintutkimuksen erään version populistinen eetos on 2000-luvulla varsin myöhäsyntyisesti saapunut myös poliittisen viestinnän tutkimuksen piiriin. Tätä näkemystä analysoidaan ja kommentoidaan artikkelin loppupuolella.

Eri tutkimusperinteet ovat suhtautuneet eri tavoin populaarin median tapaan esittää politiikka. Vanhempi traditio on suhtautunut viihteellisen median yhteiskunnallisiin vaikutuksiin kriittisesti ja pessimistisesti. Uudemmassa poliittisen viestinnän tutkimuksessa, jota artikkelissa edustaa erityisesti John Cornerin ja Dick Pelsin (2003) toimittama teos Media and the Restyling of Politics, korostuu puolestaan mediamyönteisyys ja optimismi. Vanhempi näkemys kumpuaa kriittisen poliittisen ekonomian perinteestä, uudella taas on juurensa kulttuurintutkimuksessa. Erilaiset suhtautumistavat voidaan nähdä myös modernin ja postmodernin asenteen eroiksi, kuten Anu Koivunen ja Mikko Lehtonen toteavat (Koivunen \& Lehtonen 2005, 4). Asetelma on joka tapauksessa merkillisen nurinkääntynyt: optimisminhan piti kuulua valistuksen ja modernin edistyskertomukseen, kun taas postmodernin piti suhtautua edistykseen nihilistisesti.

Tässä artikkelissa päädytään siihen, että median vanhaa kriittistä rappiotarinaa ei kannata korvata kritiikittömästi optimistisella kertomuksella populaarin median demokratiaa edistävästä vaikutuksesta. On nimittäin realistista ajatella, että muutos ei tuo mukanaan vain hyvää tai huonoa, vaan luultavasti molempia. Tarkastelen artikkelissa uutta koulukuntaa kriittisesti, mutta moderniin teoriaan palaamisen sijaan pyrkimykseni on pikemminkin positioitua (mahdollisesti) tulossa olevaan seuraavaan dialektiseen vaiheeseen, jossa nähdään paitsi modernin myös postmodernin rajoittuneisuus. ${ }^{7}$

On lisäksi muistettava, että suhtautuminen käsiteltävään kysymykseen riippuu myös tutkijan omasta tutkimuksellisesta ja käytännöllisestä asemoitumisesta. Kun elokuvan, populaariviihteen, popmusiikin tai televisiosarjojen tutkijat ulottavat kiinnostuksensa myös uutisjournalismiin, heidän taustansa näkyvät uutisjournalismin ymmärtämisen tavoissa. Vastaavasti journalismin tutkijat, jotka ovat saaneet toimittajakoulutuksen ja työskennelleet journalisteina, käsittävät viihteellistymisen omanlaisestaan positiosta käsin. Uskon, että oma asemoitumiseni luo edellytyksiä nähdä tarkasteltava aihe monelta kannalta. Olen aloittanut akateemisen urani populaarikulttuurin tutkimuksen parissa (Karvonen 1988, 1991a ja b, 1992, 1993 ja 1995). 
vuosien ajan, niin uutistoimittajana kuin keveiden viihdesivujenkin tekijänä. Tutkijan asemoituminen journalistin positioon olisi kuitenkin ongelmallista, koska toimittajat ovat yksi kiistan puolueellinen osapuoli. Omalla kohdallani organisaatioviestinnän tutkimukseni auttavat näkemään asiaa myös journalismin kohteiden, esimerkiksi poliitikkojen kannalta.

\section{POLIITIKKOJEN TIRKISTELY KONTEKSTISSAAN}

Poliitikkojen yksityiselämän paljastelu on kansainvälinen ilmiö. Brittiläinen Parliamentary Affairs -lehti omisti teemanumeronsa (2004) poliitikkojen henkilökohtaisten asioiden mediakäsittelylle eri maissa. Numeron toimittajat James Stanyer ja Dominic Wring toteavat:

Ennen henkilökohtaisina pidettynä asioita selostetaan ja kommentoidaan nykyään laajasti niin "laatumediassa" kuin"populistisissa" mediaformaateissakin. Tämä on johtanut siihen, että entisiä julkisen ja yksityisen rajoja ollaan vetämässä uudelleen. (...) Täällä ja kaikkialla muuallakin vahvistuu huomio, että senioripoliitikoista on tullut pääesiintyjiä jonkinlaiseen kansalliseen ( $\mathrm{ja}$ ajoittain globaaliin) saippuaoopperaan. (Stanyer $\&$ Wring 2004, 1-2)

Teemanumeron toimittajien mukaan maat jakautuvat poliitikkojen yksityisasioiden mediakäsittelyssä kahteen ryhmään. Iso-Britannia ja Yhdysvallat edustavat maita, joissa yksityiset asiat ovat vapaata riistaa medialle. Ranska, Saksa, Espanja, Intia ja Uusi-Seelanti taas ovat maita, joissa politiikkojen yksityiselämää ei pahemmin repostella. Sama pätee myös Lähiidän maihin ja Venäjään.

Iso-Britannia on poliitikkojen yksityiselämän paljastelussa ehkä pisimmällä. Siellä mediateollisuuden kilpailutilanne on rajuimpia koko maailmassa. Kymmenen valtakunnallista iltapäivälehteä taistelee joka päivä kiivaasti yleisön huomiosta. Valtakunnallisia päivälehtiäkin on yhdeksän. Kaikki nämä lehdet pitävät tukikohtanaan Lontoon seutua, ja kaikki ne myydään irtonumeroina, minkä vuoksi tietty sensaatiomaisuus on todennäköistä. Kilpailutilanteesta on seurannut vahvasti iltapäivälehtimäinen journalistinen kulttuuri. Tämä ilmenee osin myös sähköisen median puolella. Lisäksi Iso-Britannian lain mukaan kansalaisten yksityisyyden suoja on heikko. (Beacon 2004). Sen sijaan esimerkiksi Ranskassa ja Saksassa poliitikonkin yksityisyys on varsin hyvin lailla suojattu. Ranskassa toimittajat ja myös yleisö ovat olleet haluttomia penkomaan poliitikkojen yksityiselämää - tosin nyt tilanne on muuttumassa presidentti Nicholas Sarkozyn julkkismaisen käytöksen myötä.

Eräs historiallinen rajapyykki poliitikon yksityisasioiden paljastamisessa oli demokraattisen puolueen presidenttiehdokkaaksi pyrkineen Gary Hartin syrjähypyn julkistaminen yhdysvaltalaisessa mediassa vuonna 1987 (Kurtz 1994; Karvonen 2000a). Aikaisemmin poliitikkojen, esimerkiksi John F. Kennedyn, romansseista ei kerrottu julkisuudessa, vaikka toimittajat olivat niistä tietoisia. Toisaalta Richard Nixonin Watergate -skandaali 
1970-luvun alussa oli opettanut journalistit kriittisiksi poliitikkoja kohtaan. Hartin tapauksessa oli kysymys tilanteesta, jossa hänen huhuttiin tapailevan nuorta mallia samaan aikaan, kun hän julkisuudessa rakensi itsestään nuhteettoman perhepoliitikon imagoa. Hart kielsi huhut ja yllytti mediaa tarkkailemaan itseään. Toimittajat pystyivätkin esittämään vakuuttavia todisteita suhteesta, mikä johti Hartin suosion romahtamiseen ja luopumiseen ehdokkuudesta. Hartin tapauksessakin kirjoitettiin niin sanottuja luonnetodistuksia (character witness), jotka kuuluvat Yhdysvalloissa paitsi oikeuskäytäntöön myös journalismiin. Luonnetodistuksia käytetään arvioitaessa viranhakijan kelpoisuutta vastuulliseen virkaan sekä heikkouksia kartoitettaessa.

Toinen merkkitapaus on Yhdysvaltain presidentti Bill Clintonin ja harjoittelija Monica Lewinskyn seksisuhteen käsittely mediassa vuonna 1998. Osaksi internetin Drudge Report -palvelun ${ }^{8}$ julkean raportoinnin vaikutuksesta myös arvovaltaiset lehdet ja uutiskanavat käsittelivät ennätysmäisen yksityiskohtaisesti esimerkiksi "spermatahroja sinisessä koltussa". Drudge Report julkaisi paljastuksen ensimmäisenä, ja muu media joutui muuttamaan käytäntöjään pysyäkseen uutiskilpailussa mukana. Pääasiaksi nousivat tässäkin kohussa luonnetodistus ja Clintonin valehtelu.

Suomessa poliitikkojen yksityiselämän paljastelu mediassa on saanut selkeitä vaikutteita anglosaksisesta journalismista ${ }^{9}$. Kunnioittava suhtautuminen poliitikkoihin on nuoremman toimittajapolven myötä vaihtunut riippumattomuutta korostavaksi ja kriittiseksi (Aula 1991, journalistien riippumattomuudesta ks. esim. Karvonen 2008). Poliittisten toimittajien vuonna 1981 kirjoittaman Tamminiemen pesänjakajat -kirjan myötä median kunnioittava suhtautuminen poliitikkojen yksityiselämää kohtaan mureni. Syynä muutokseen oli muun muassa Urho Kekkosen sairauteen liittyvä salailu. Kirjan ilmestymisen myötä politiikan uutisoinnin kulttuuri Suomessa muuttui selvemmin vallan vahtimiseksi (Väisänen 1992).

Poliitikkojen persoonan esiintuominen mediassa alkoi Suomessa vuoden 1983 eduskuntavaaleista naisedustajien johdolla ( $\mathrm{mm}$. Arja Alho ja Sirpa Pietikäinen). Muutamaa vuotta myöhemmin myös miespoliitikkojen persoonat nousivat esiin. Yksi henkilökuvien ensimmäisistä piirtäjistä oli $\mathrm{Hel}$ singin Sanomien Kuukausiliite, joka tarjosi poliitikoille suurta ja yleensä myönteistä julkisuutta. Myöhemmin "kuluttajavalistuksen" nimissä poliitikoiden persoonista alettiin kirjoittaa myös kriittisiä arvioita (Pernaa, Pitkänen $\&$ Railo 2006, 46-54).

Tässä artikkelissa keskitytään käsittelemään poliitikkojen ja journalismin suhdetta lähihistoriassa. Kauemmas historiaan ulottuva tarkastelu voisi tuoda esiin toisenlaisia näkymiä. Tässä ei ole käsitelty esimerkiksi sitä, miten poliittiset liikkeet ovat käyttäneet huumoria ja viihdettä aseena vihollisiaan vastaan. Suomalainen politiikka ja poliittiset lehdet vaikkapa fennomanian aikakaudella tarjoaisivat tästä mehukkaita esimerkkejä. Toisaalla tässä numerossa Anu-Hanna Anttila, Ralf Kauranen ja Pekka Rantanen (2008) esittelevät viihteellisyyden osuutta 1900-luvun alun suomalaisten sosialistien politiikassa. 


\section{KOHUT, KESKUSTELUT JA MEDIAN HUOMIOVALTA}

Edellä mainitun "Monicagaten" mediakäsittely sai ennennäkemättömät mittasuhteet koko maailmassa. Le Monde Diplomatique -lehden päätoimittaja Ignacio Ramonet $(2001,15)$ kutsuu tätä yliuutisoinniksi, jolla hän viittaa siihen, että painoarvoltaan vähäinen asia voi kasvaa mediassa valtavaksi. Ramonetin mukaan tämä johtuu sitä, että tiedotusvälineet jäljittelevät ja kiihottavat toinen toisiaan, mikä synnyttää lumipalloefektin. Tällainen mediariehaantuminen toteutui myös Suomen poliitikkoskandaaleissa.

Median tai suppeammin journalismin valta on ennen kaikkea valtaa asettaa agenda, josta kansakunta keskustelee. Agenda setting -teorian luoja Maxwell McCombs $(2004,1)$ kirjoittaa: "Päivästä toiseen tapahtuvan uutisten valikoimisen ja esittämisen kautta toimittajat ja uutispäälliköt kohdistavat huomiotamme ja vaikuttavat havaintoihimme siitä, mitkä ovat päivän tärkeimmät keskustelukysymykset (issues)". Tähän voidaan Thomas Davenportin ja John Beckin (2001) pohjalta jatkaa, että elämme "huomiotaloudessa", jossa ihmisten vastaanottokyky on rajallinen, ja siksi huomion saamisesta on tullut taloudellisesti arvokas resurssi. Kun onnistuu samaan informaatiotulvan kakofoniassa huomiota omalle asialleen, on jo voittanut jotakin.

Erityisesti iltapäivälehdet hallitsevat huomion kiinnittämisen taidon: ne pystyvät saattamaan uutisoimansa asiat jokaisen tietoisuuteen. Poliitikkojen julkisuuden tapauksessa iltapäivälehdillä on valta asettaa vaikkapa pääministerin lähettämä tekstiviesti viikon tärkeimmäksi keskustelunaiheeksi. Media onkin yhä enemmän juuri keskustelun herättäjä ja foorumi. Iltapäivälehden sivusto ilmoittaa olevansa "Suomen puheenaiheportaali" (Iltalehti). Myös muun median painotuksissa tiedonvälitysfunktion rinnalle on noussut keskustelufunktio, mahdollisesti internetin tarjoaman vaivattoman ja anonyymin vuorovaikutteisuuden ansiosta.

Keskustelun lisääntyminen yhteiskunnassa on periaatteessa hyvä asia. Hermeneutiikan opetusten mukaan kaikki ymmärrys on aluksi yksipuolista ja ennakkoluuloista, mutta monipuolistuu dialogissa. Eri tavoin asemoituneet ihmiset kykenevät vuoropuhelun myötä näkemään asioita myös toisen kannalta, ja näin päästään rakentamaan eri osapuolia paremmin tyydyttävää todellisuutta. Hermeneutiikka voi olla pohjimmiltaan toiseuden ymmärtämistä. (Gadamer 2004, 29-39; Betti 2005, 108-121).

Voidaan kuitenkin kysyä, onko mikä tahansa keskustelu aina itseisarvoisesti sellaista, että se rakentaa parempaa yhteistä todellisuutta (vrt. Schudson 1997). Keskusteluhan voi olla vaikkapa rasistista vihaan yllyttämistä tai matalamielistä panettelua. Ei ole myöskään itsestään selvää, että politiikkojen yksityiselämän kiemuroista keskusteleminen rakentaa parempaa huomista. Jürgen Habermasin (2004) esittämän porvarillisen julkisuuden ideaalina on kriittis-rationaalinen, tasaveroinen keskustelu yhteisistä asioista (ideaalin kritiikistä ks. esim. McKee 2005). Kaikenlainen keskustelu ei näitä vaatimuksia täytä.

Journalismin painottuminen puheenaiheiden tarjoamiseen ja keskustelun herättämiseen voi muuttaa uutisarvostuksia. Parhaiten keskustelua herättävät voimakkaasti mielipiteitä jakavat kysymykset, tunteita kuohuttavat tapaukset tai yksipuoliset provokaatiot, ei niinkään objektiivinen 
uutisointi ja analyyttinen puntarointi. Kaupallisen median piirissä on huomattu, että poliitikkojen yksityiselämän tirkistely kiinnostaa ihmisiä ja myy hyvin. Jokainen voi tuntea olevansa pätevä keskustelemaan ihmissuhdekuvioista, toisin kuin usein hankaliksi koetuista politiikan asiakysymyksistä. Toisaalta henkilökohtaisista asioista uutisoiminen tarjoaa mahdollisuuden nostaa käsittelyyn laajasti yhteiskunnallisesti merkittäviä kysymyksiä.

Alkuperäisessä muodossaan McCombsin agenda setting -teoria väitti, että media määrää ihmisten puheenaiheita, mutta ei heidän ottamiaan kantoja asioihin (McCombs \& Shaw 1972). Tämän vuoksi agenda setting -teoriaa on usein täydennetty tulkintakehysten (frame analysis) teorialla. Paljon siteeratussa määrittelyssään Robert Entman $(1993,52)$ kirjoittaa: "Kehystäminen on joidenkin puolien valitsemista havaitusta todellisuudesta ja niiden tekemistä muita näkyvämmäksi viestivässä tekstissä, niin että suositaan ja edistetään tiettyä ongelmanmäärittelyä, kausaalista tulkintaa, moraalista arviota ja/tai toimintasuositusta." Uusimmassa tuotannossaan McCombs (2004, 86-97) määrittelee kehystämisen "toisen tason" agenda settingiksi. Ensimmäisen tason agendan asettamisessa valitaan huomion ja keskustelun kohteet, toisen tason agendassa valitaan ne todellisuuden puolet, joihin huomio halutaan ohjata (ks. myös Karvonen 2000b; Entman 1991, 9).

Media ei siis ole tasasuhtainen peili ${ }^{10}$, vaan joitakin asioita suhteettomasti suurentava ja toisia pienentävä peili. Kohujen aikaan poliitikon yksityisasiat saavat valtaisan huomion osakseen. Näin poliitikkojen yksityiselämään suuren huomion kiinnittävä media käyttää valtaa ja tuottaa tietynlaista sosiaalista todellisuutta. Myös politiikan asiakysymyksistä raportoidaan, mutta ainakin suurten kohujen aikaan ne kutistuvat näkyvyydeltään vähäiseen rooliin. Toisaalta on kuitenkin huomattava, että erilaisilla eliiteillä ja aktivisteilla on paljonkin valtaa määritellä mediassa keskusteltavista asioista (Suhonen 1994).

\section{POLITIIKAN JA MEDIAN MUUTOKSET}

Kent Asp ja Peter Esaiasson (1996) kuvaavat empiirisen tutkimuksensa nojalla ruotsalaisten vaalikampanjoiden muuttumista 1950-luvulta 1990-luvulle. He puhuvat kampanjoinnin modernisoitumisen prosesseista, joihin kuluvat politiikan yksilöllistyminen, ammattimaistuminen ja medioituminen (emt. 74). Keskiluokkaa kosiskelevat puolueet ovat muuttuneet samankaltaisiksi, puolueisiin sitoutuminen on romahtanut ja liikkuvien äänestäjien joukko kasvanut. Henkilöt, erityisesti puoluejohtajien persoonat, ovat tulleet tärkeiksi. Puolueita johdetaan kuin liikeyrityksiä, markkinatutkimuksia tehden ja (vaali)voittoa tavoitellen. Medioituminen on merkinnyt median irtaantumista puoluekytköksistä, median vaikutusvallan lisääntymistä, politiikan tulemista riippuvaiseksi mediasta ja poliitikkojen yrityksiä käyttää hyväksi mediaa. Samansuuntaista kehitystä on tapahtunut muissakin läntisissä demokratioissa, myös Suomessa (ks. Moring \& Himmelstein 1993 sekä Moring 2008).

Samalla myös media on medioitunut, eli tullut yhä riippuvaisemmaksi toisista medioista, ja markkinaehtoistunut (esim. Luostarinen \& Uskali 
2004; Wiio 2006; Olkinuora 2006). Yhtäältä tämä voidaan tulkita asiakaslähtöisyydeksi, herkkyydeksi ottaa huomioon eri asiakasryhmien erilaiset tarpeet ja kiinnostukset. Tältä kannalta katsoen on vain hyvä, että media on oppinut palvelemaan ihmisiä paremmin kuin ennen. Toisaalta markkinaehtoistuminen voidaan tulkita kielteisen sivumerkityksen kera kaupallistumiseksi, sensationalisoitumiseksi ja iltapäivälehtimäistymiseksi (eli tabloidisoitumiseksi). Näin kyse olisi asiajournalismin rappeutumisesta.

Niin sanotun laatumedian edustajat eivät mielellään myönnä tabloidisoitumista tapahtuneen. Monet iltapäivälehtien edustajat kuitenkin katsovat, että tämäntyyppinen journalismi on ollut esikuva muullekin medialle."Vakavan uutisjournalismin edustajina esiintyneet aamulehdet ja television uutislähetykset ovat omaksuneet iltapäivälehtien toimintatapoja ja esitystyylejä sitä mukaa kun niiden oma kilpailuasema on heikentynyt." (Pietilä 2007, 72). Tähän näkemykseen yhtyy myös Kivioja, joka hänkin on taustaltaan iltapäivälehden toimittaja (Kivioja 2008a, 18).

Medioituminen on yhtäältä sitä, että ihmisten tiedot maailmasta ovat nykyisin mediavälitteisiä ja median suodattamia: politiikasta muodostuva kuva riippuu paljolti mediaesityksistä. Toisaalta syvällisemmässä mielessä medioituminen on muiden yhteiskunnan instituutioiden, kuten politiikan, sopeutumista medialogiikkaan, jotta oma asia saataisiin esiin julkisuudessa. Näin media voi rakenteistaa muuta yhteiskuntaa. Asp ja Esaiasson (1996) ovat selittäneet politiikan medioitumisen prosessin kolmea vaihetta ruotsalaisessa yhteiskunnassa. Ensimmäisessä vaiheessa 1960-luvulla mediasta tuli hallitseva viestintäkanava hallitsevien ja hallittujen välillä. Poliitikko pystyi saamaan yhteyden äänestäjiin parhaiten tiedotusvälineiden kautta, politiikka tuli riippuvaiseksi median palveluksista. Toisessa vaiheessa 1970-luvulla mediasta tuli puolueista riippumaton, kaupallinen, markkinaehtoinen toimija. Journalistisessa kulttuurissa alettiin yhä enemmän korostaa professionaalisuutta, lahjomattomuutta ja kriittisyyttä. Mediasta tuli yhä vahvempi vallankäyttäjä yhteiskunnassa. Vihdoin kolmannessa vaiheessa 1980-luvulla Ruotsin poliittiset toimijat käsittivät riippuvuutensa mediasta ja alkoivat sopeuttaa toimintaansa sen asettamien ehtojen mukaiseksi, muokkaamaan itseään "mediaseksikkäiksi" ja miettimään keinoja suotuisan julkisuuden saamiseksi.

Tämänsuuntainen kehitys on saanut politiikan tutkija Thomas Meyerin (2002) kirjoittamaan siitä, kuinka media "kolonisoi politiikan", tai siis alistaa sen omaan toimintalogiikkaansa. Toisaalta tämä kehitys on näyttäytynyt erityisesti anglosaksisten maiden journalisteille kielteisesti poliitikkojen harjoittamana manipulointina, uutistenohjailuna ja PR-ammattilaisten johtamana imagonrakentamisena. Mediajulkisuudesta on joka tapauksessa tullut elintärkeä tekijä ja toimittajasta tämän strategisen voimavaran vartija. Syntyy "julkisuuspelinä" tunnettu asetelma (Uimonen 1992; Moring \& Himmelstein 1993; Luostarinen 1994; Karvonen 1999a, 33-36). Suomessa politiikan medioituminen on tapahtunut ilmeisesti hieman myöhemmin kuin Ruotsissa.

Poliitikon näkökulman aiheeseen esittelee pitkän poliittisen uran tehnyt Arja Alho. Hän tekee väitöskirjassaan (Alho 2004) tapaustutkimustensa nojalla muun muassa seuraavia johtopäätöksiä: a) medioituminen on joh- 
tanut siihen, että poliittisten skandaalien syntyessä aloite asioiden hallitsemisesta siirtyy poliittiselta eliitiltä medialle; b) median viihteellistyminen ja tabloidisaatio korostuvat journalismin uudessa eetoksessa; c) julkinen sfääri ei toimi ideaalilla tavalla rationaalis-kriittisen keskustelun foorumina ja d) suomalainen media on enemmän äänekästä kuin analyyttista. Täten mediassa on poliitikon näkökulmasta paljonkin vikaa. Näin ovat todistaneet myös huippupoliitikot Kalevi Sorsa (median "infokratia") ja Mauno Koivisto (toimittajat"sopuleina").

Poliitikot ja toimittajat kiistelevät siitä kumpi aloitti julkisuuspelin, kuka on "syypää" median pyörittämiseen ja kuka käyttää hyväksi ketä. Poliitikkojen näkökulmasta media kohuaa usein epäolennaisista asioista. Suhtautumalla kyynisesti ja vihamielisesti politiikkaan media murentaa ihmisten halua osallistua politiikkaan ja näin heikentää demokratiaa. Journalistisesta näkökulmasta katsottuna taas poliitikot ovat olleet aloitteellinen osapuoli persoonansa esiintuomisessa ja viihteellisessä markkinoinnissa. Journalismi on joutunut reagoimaan imagomarkkinointiin tuomalla esiin kuluttajavalistuksen hengessä sen, mitä myyntipuheiden takaa todella paljastuu. Poliitikot odottavat saavansa ilmaista mainostilaa medioista ja yrittävät ujuttautua hyviin väleihin toimittajien kanssa taatakseen suotuisan esillä olon. Anglosaksisten maiden hallitukset manipuloivat yleistä mielipidettä ammattimaisten PR-ihmisten taitavilla operaatioilla. Portinvartijana toimittajan on siis oltava tiukka, lahjomaton, kriittinen ammattilainen, joka paljastaa totuuden (ks. esim. Uimonen 1992; Karvonen 2008) Tutkimuksen näkökulmasta on kuitenkin hedelmällisintä ajatella politiikan ja median suhdetta loputtomana vuorovaikutuksena, kädenvääntönä sekä siirtojen ja vastasiirtojen sarjana, jota voidaan seurata taaksepäin historian hämärään. Valtapelissä median asema näyttää vahventuneen ja politiikan heikentyneen.

\section{POSTMODERNIT MUUTOKSET: ESTETISOITUMINEN JA EMOTIONALISOITUMINEN}

Monet mediasosiologit selittävät länsimaisessa kulttuurissa tapahtuneita muutoksia siirtymisellä modernista aikakaudesta postmoderniin aikaan. Kevin Glynn (2000, 17-18) toteaa, että erottelu yksityiseen ja julkiseen kuului modernin aikakauden kulttuuriin. Postmodernissa yhteiskunnassa tämä erottelu on hämärtymässä. Samoin hämärtyy todellisuuden ja esityksen ero sekä uutisen ja viihteen ero. Estetiikka, tyyli ja tunteet tulevat tärkeiksi, siinä missä moderni palvoi objektiivista, universaalisti pätevää tietoa ja järkeä.

Corner ja Pels $(2003,8)$ toteavat, että nyky-yhteiskuntaa luonnehtii prosessi, jossa yhteiskunnan eri alueiden erilaiset toimintalogiikat tunkeutuvat toinen toisiinsa. Talouden logiikat tulevat politiikkaan, jossa aletaan soveltaa markkinoinnin, markkinatutkimuksen, brändäyksen ja asiakaslähtöisyyden ideoita. Samaan aikaan kulttuurin tai taiteen alueen esteettisyys tunkeutuu sekä talouteen että politiikkaan. Läpikotaisin estetisoituneessa, merkkien ja symbolien läpäisemässä kapitalismissa puolue tai ideologia voi säilyä hengissä vain brändinä ja ainoa tulevaisuus poliittiselle persoonalle 
on julkkiksen olomuoto. Tähän voitaisiin vielä lisätä, että myös talous on politisoitunut muun muassa eettisen kuluttamisen (luomu, reilu kauppa jne.) lisääntymisen myötä.

Corner ja Pels (emt. 8-9) toteavat, että juuri mediakulttuuri toimii keskeisenä erillisten alueiden purkajana ja pakottaa "tyylivallankumouksen" muille sosiaalisille alueille, jolloin toteutuu samanaikaisesti estetisaation, emotionalisaation ja "julkkistumisen" (celebrification) prosessi (emt. 8). Heidän mukaansa nykyajan esteettinen politiikka ei ole tiedettä vaan taidetta. Poliittinen edustaminen/esittäminen noudattaa pikemminkin romantiikan tradition mukaista esteettistä logiikkaa kuin rationaalista valistuksen logiikkaa. Politiikka teatterina, spektaakkelina, tyylinä, tunteena ja persoonallisuuden kulttina otettiin voimaperäisesti käyttöön oikeistolaisissa 1900-luvun alkupuolen liikkeissä (fasismi, natsismi) ${ }^{11}$. Jo varhain 1900-luvulla myös keskusta-vasemmistolaiset liikkeet alkoivat kopioida näitä menestyksellisiä oppeja itselleen. Nykyisin esteettinen tyylitietoisuus on kirjoittajien mukaan välttämätön postmodernin joukkopolitiikan piirre.

Samantapaisia prosesseja ovat panneet merkille muutkin tutkijat. Richards (2004) toteaa, että vaaleissa menestyy se, joka tunnistaa vallitsevan yleisen tunnelman ja onnistuu vetoamaan siihen viestinnässään. Tarvitaan tunteiden johdattelua (management of feelings). Ihmiset vaativat nykyisin elämänmakuisia, leikkisiä, emotionaalisesti mutkikkaita esityksiä. Tyyli on tärkeää - ei se mitä sanotaan, vaan miten sanotaan.

Veijo Hietalan (2007) mukaan elämme "uusromantiikan" aikaa vastareaktiona valistuksen järjen kulttuurille. Nykyisen elämys- ja tunnekultuurin on hänen mukaansa saanut aikaan niin sanottu tunnemedia, eli televisio ja elokuva. Hietala toteaa, että tirkistely on ollut olennainen osa kulttuuriamme elokuvan synnystä alkaen (emt., 60). Hän toteaa tirkistelyn olevan luonnollinen asia, josta on turha syyllistää ihmisiä. Hietala selittää jopa tv-uutiset viihteeksi ja populaarikulttuuriksi: uutisten katselu on sekin nautinnollista tirkistelyä. Maija-Riitta Ollila $(2005 ; 2006)$ ottaa sitä vastoin kriittisen kannan poliitikkojen yksityisyyden tirkistelyyn. Entisestä seksuaalisen tirkistelyn (voyerismin) paheesta on tehty nykyisin demokraattisen kontrollin hyve. Ollila kysyy, mitkä ovat lopulta hyväksyttäviä perusteluja ihmisen yksityiselämän suojan murtamiseksi, ja toteaa, että journalismi määrittelee näiden kysymysten tulkintaa koko yhteiskunnassa (Emt., 36).

Anu Koivunen (2008) luo katsauksen siihen, kuinka aiemmin laiminlyöty tunteiden tutkimus puskee nykyään esiin laajalla rintamalla. Koivunen haluaa dekonstruoida tunteen ja järjen vastakohtaisuuden, joka on vallinnut suomalaisessa mediatutkimuksessa jopa siinä märin, että huomiota on kiinnitetty vain järkeen ja asiallisuuteen. Koivusen (emt., 18) mukaan tunteet ja kokemuksellisuus tulee nostaa tutkimuskohteiksi ja modernismin perintöön kuuluvasta tunteen epäilystä tulee päästä eroon. On totta, että tunteen vastakohta ei ole järki, vaan tunteettomuus, kun taas järjen vastakohta järjettömyys.

Tunteiden huomioon ottaminen ei silti ole mikään uusi asia. Itse haluan kiinnittää huomiota esimerkiksi Aristoteleen retoriikkaoppiin (1997), jonka mukaan puhuja säätelee kuulijakunnan tunnepitoisuuden ("liikut-

Tiedotustutkimus 2008:5 
tuneisuuden") astetta tarkoitusperiensä mukaan: joskus on tarpeen kiihottaa kansa raivoon ja sotaan, toisinaan taas on tarkoituksenmukaista rauhoittaa heidät harkitsemaan huolellisesti seuraamuksia. Nykypäivän tabloidit edustavat tunteisiin vetoamista, kiihottamista ja kuohuttamista. Asiajournalismi taas on puhuttelutavaltaan edustanut tunteita tyynnyttävää ja harkinnalle tilaa antavaa retoriikkaa. Tunne ja järki eivät ole vastakohtia, vaan erillisiä ulottuvuuksia: metaforisesti kuin musiikin tai kuvankäsittelyn säätöpöydän säätimiä, joilla voi lisätä tai vähentää bassojen voimakkuutta tai värikylläisyyttä. Tunteisiin vetoamista voidaan siis säädellä. Yleisen elämänkokemuksen valossa voidaan arvioida, että voimakas tunnekuohu haittaa harkintaa. Voidaan myös kysyä, tarvitaanko jo ennestään järkyttävien tapausten (kuten kouluampumisten) yhteydessä vielä tunnekuohun lisäämistä.

\section{POLIITIKOISTA JULKKIKSIKSI}

\section{David Giles kirjoittaa, että nykyään}

"kaikkia kuuluisia ihmisiä kohdellaan kuin julkkiksia, olipa
kyseessä merkittävä poliittinen figuuri, kiitetty urheilija,
'nerouden koskettama artisti, sarjamurhaaja tai Driving
School tosi-tv ohjelman Maureen. Näiden julkisuudesta vas-
tuussa olevat lehdet tai televisio-ohjelmat eivät tee juurikaan
eroa sen suhteen miten heidät julkistetaan. (Giles 2000, 5)

Graeme Turner (2004) katsoo kuitenkin tarpeelliseksi tehdä eron julkisuuden henkilön (public figure) ja julkkiksen (celebrity) välille. Julkisuuden henkilö on esillä mediassa"työroolinsa" puitteissa olipa hän sitten urheilija, artisti, tutkija, virkamies, kauppias tai poliitikko. Kun sitten median ja yleisön huomio alkaa kiinnittyä ensisijaisesti henkilön yksityiselämän detaljeihin, tai poliitikosta aletaan kiinnostua "ihmisenä" tai persoonana, hän on muuttunut julkkikseksi. Tätä muutosta työroolin puitteissa toimivasta julkisuuden henkilöstä yksityiselämältään kiinnostavaksi persoonaksi Turner kutsuu julkkistumisen (celebritisation) prosessiksi (Turner 2004, 8). Esimerkiksi Vanhanen, Kanerva ja Karpela ovat ministereinä voineet esiintyä mediassa työasioissaan julkisuuden henkilöinä. Kohujen yhteydessä he sen sijaan saivat osakseen julkkiksen kohtelun. (Poliitikon omasta halusta esiintyä julkkiksena ks. Street 2003 ja 2004.)

Daniel Boorstinin (1962) tautologisen ja ironisen julkkiksen määritelmän mukaan "Julkkis on henkilö, joka on tunnettu siitä että on hyvin tunnettu". Ennen vanhaan oli vielä tapana, että henkilö tuli kuuluisaksi saavutustensa perusteella, mutta nyt ansioita ei enää tarvita. Riittää, että henkilö on TV:n kaikille tutuksi tekemä "kasvo". Myös Turner myötäilee Boorstinin näkemystä:

Nykyajan julkkiksen kuuluisuus ei välttämättä riipu siitä asemasta tai niistä saavutuksista, jotka alun alkaen antoivat hänelle medianäkyvyyttä. Pikemminkin julkkikseksi tulon jälkeen hen- 
kilön alkuperäiset ansiot jäävät sivuseikaksi. Itse asiassa nykyjulkkiksella ei ole muita vaateita kuin kyky herättää kiinnostusta yleisössä. (Turner 2004, 3)

Ja kiinnostusta julkkikset herättävätkin. Noin puolet iltapäivälehden lööpeistä pyrkii myymään julkkiksen avulla (Kivioja 2004).

Turnerille $(2004,9)$ "julkkismaisuus" ei ole henkilön ominaisuus vaan median esittämisen tapa, genre ja diskursiivinen efekti. Poliitikot joutuvat yhdessä tv -tähtien, rock-artistien ja tosi-tv:n esiintyjien kanssa saman julkisuutta tuottavan myllyn käsittelyyn. Julkkiksena esittämiseen kuuluu säännönmukaisesti julkisen ja yksityisen rajan ylitys (emt. 8). Julkisen "tähteyden" takaa paljastetaan yksityinen "todellinen minä". Paljastamisen liike tuo ilmi, että kuuluisa ja korkeassa statuksessa oleva henkilö onkin itse asiassa aivan "tavallinen" kuolevainen ongelmineen. Tavallisesta ihmisestä voikin tuntua lohduttavalta huomata, että julkkiksilla on samanlaisia ongelmia kuin muillakin ihmisillä. Julkkisten funktio olisi täten terapeuttinen: heidän kauttaan ihmiset voivat työstään omia murheitaan (Richards 2004). Tähteyden erikoislaatuisuus ja toisaalta tavallinen ihmisyys kuuluvatkin mediaesityksissä yhteen (vrt. van Zoonen 2005).

Julkkiksen tai poliitikon palauttaminen "tavalliseksi ihmiseksi" ei ole poliitikon kannalta välttämättä huono asia. Poliitikkohan pyrkiikin olemaan "yksi meistä" (kuten Tarja Halosen vaalikirjan nimi todistaa ${ }^{12}$ ) eikä suinkaan ihmisistä vieraantunut "herra". Identiteettipoliittisesti omaksi edustajakseen kannattaa valita itsensä kaltainen henkilö, joka ymmärtää tavallisen ihmisen, naisen, duunarin, maanviljelijän, ruotsinkielisen jne. tarpeet (Karvonen 2007a). Keskustapuolueen vuoden 2007 eduskuntavaalien iskulausekin ilmensi identiteettipolitiikkaa: "Vähän kuin itseäsi äänestäisit!". Siten Matti Vanhasen lemmenhetkiin liittyvistä paljastuksista on saattanut olla hänelle myös hyötyä, vaikka hän onkin vaatinut rangaistuksia yksityisyyden loukkaamisesta. Pääministeri Vanhasesta on tullut kaikkien tuntema"Matti".

\section{VIIHTEELLISTYYÄ POLITIIKAN JULKISUUS?}

Suomen kielen sana "viibde" tarkoittaa "kevyttä ajanvietettä". Se tulee verbistä "viihdyttää": (koettaa) saada joku viihtymään, huvittaa, hauskuttaa. Yleisesti viihteellisen vastakohtana käytetty "vakava" merkitsee: totinen, nauramaton, syvällinen (vs. pinnallinen, hilpeä, tms.; Suomen kielen perussanakirja). Englannin kielen "entertainment" ja "amusement" viittaavat hilpeään, keveään, mukavaan ajankuluun, kiinnostavuuteen, virkistykseen ja nautinnolliseen. Vastakohta "serious" taas viittaa vakavaan, tärkeään ja painavaan ${ }^{13}$. Arkisesti itsestään selvä käsite osoittautuu lähemmässä tarkastelussa kuitenkin monimutkaiseksi ja hankalaksi. Onko viihdyttäminen esimerkiksi tekijän intention asia, tekstin genren asia, vastaanottajan reseption asia vai vastaanottajalle tarjotun roolin asia? (Ekström 2000, 466-467). Arkikielessä on tavallista puhua "politiikan viihteellistymisestä". Itse viihteellistymisen käsite on kuitenkin myös ongelmallinen. Puhuttaessa "politiikan viihteellistymisestä” jää epäselväksi, onko itse politiikan professio 
muuttumassa showbisnekseksi, vai onko politiikan mediajulkisuus saamassa viihteenomaisia piirteitä ${ }^{14}$. Tässä artikkelissa keskitytään jälkimmäiseen kysymykseen, eli mediajulkisuuden tarkasteluun.

Jokapäiväisessä elämässämme kysymme puhekumppanilta: pelleiletkö vai oletko tosissasi? Käytännön elämässä on hyvin tärkeää tietää, onko esimerkiksi hälytys otettava todesta vai onko kyseessä vain pila. Uutismedian liiketoiminnan perusta on lähtökohtaisesti luotettavassa informoinnissa, joten mediatalot eivät mielellään vaaranna uskottavuuttaan ja tuhoa bisnestään. Siksi viihde ja mielipiteet sijoitetaankin omiksi erillisiksi lajityypeikseen (genre), joihin yleisö osaa suhtautua asiaankuuluvasti. Lajityyppien sekoittuminen voi herättää yleisössä hämmennystä ja ärtymystä. Pelleily ja tosissaan oleminen ovat erilaisia ihmisenä olemisen tapoja tai "maailmaa kohti suuntautumisen tapoja" ${ }^{15}$. Retoriikallaan viestijät antavat yleensä vihjeitä siitä miten viestiin pitää suhtautua tai suuntautua. Jos vihjeet ovat ristiriitaisia ihmiset eivät voi päättää miten suhtautua ja toimia. Esimerkiksi suomalaiset ovat katsojatutkimuksissa toivoneet selkeää jakoa viihteen ja informaation välille (Jääsaari 2004; Snell ym. 2003).

Mats Ekström (2000) erottaa televisiojournalismissa kolme moodia (modes): informaation, tarinankerronnan ja attraktion. Informaatiomoodissa tarjotaan relevanttia, kiinnostavaa, luotettavaa tietoa maailmasta. Tarinankerronnan moodissa kerrotaan jännittävä tai dramaattinen kertomus.

Attraktiomoodissa vedotaan katsojiin spektaakkeleilla, shokeeraavilla tai eriskummallisilla teemoilla (emt., 467). Attraktiomoodi on kiinnostava nimenomaan iltapäivälehtimäisen esitystavan kannalta. Attraktio on värikästä kieltä ja isoja otsikoita, ja se koskee usein poikkeamaa normista ja normaalista. Se ei välttämättä ymmärrä erilaisuutta vaan korostaa tämän outoutta (Aslama 2005, 68). Attraktiot on tehty vangitsemaan yleisön mielenkiinto, herättämään voimakkaita tunteita ja ruokkimaan spontaaneja reaktioita: naurua, yllättyneisyyttä, tyrmistystä tai paheksuntaa. Attraktiot liittyvät esimerkiksi tosi-tv:n kaltaisiin mediatapahtumiin, jotka on luotu mediassa tai mediaa varten. Niissä käytetään ihmisiä jotenkin hyväksi, vaikka tähän ei välttämättä liity eettisiä ongelmia. (Ekström 2000, 477-481)

Aslama (2005), Ekström (2000) ja myös Teemu Palokangas (2007) katsovat, että informaation ja viihteen dikotomia on hedelmätön, koska nämä itse asiassa eivät ole vastakohtia. Voi olla informatiivista viihdettä, älyllisesti stimuloivaa viihdettä ja viihteellistä informaatiota. Palokangas (emt. 124) toteaa, että yleisradiossa viihteellä on usein välineellinen arvo: sillä houkutellaan katsojia kanaville ja sen avulla paketoidaan opettavainen informaatio makoisaan muotoon, "että lääke menisi paremmin alas". Viihteellistäminen on esitystekninen keino: itse asian ei tarvitse siitä kärsiä. Itse en romuttaisi informaation ja viihteen eroa, vaan näkisin ne eri suuntautumisen tapoina kuten edellä"pelleilyn" ja "tosissaan olemisen" kohdalla esitin.

Viihteellistyminen voidaan käsittää esitystavan sijaan myös sisällön trivialisoitumiseksi, jolloin uutisointi koskee joutavia pikkuasioita, joilla ei ole yhteiskunnallista painoarvoa ja merkittävyyttä. Aiheen kiinnostavuus tai viihdearvo on voinut nousta ensisijaisemmaksi uutisjournalismin kritee- 
riksi kuin asian tärkeys, yhteiskunnallinen merkittävyys tai vaikuttavuus monien kansalaisten elämään. Pääministerin makuuhuonepuuhastelun intiimit yksityiskohdat ovat monien mielestä kiinnostavia ja näitä koskevilla paljastuksilla on siten huomattava kaupallinen potentiaali. Mutta ovatko nämä seikat yhteiskunnallisesti merkittäviä?

Merkittävyys, tärkeys tai relevanssi on todenmukaisuuden ja tasapuolisuuden ohella keskeinen objektiivisen uutisoinnin kriteeri (Westerståhl 1972, 1983; Hemanus \& Tervonen 1980). Nico Carpentierin (2005, 205) mukaan objektiivisuus on edelleenkin journalistisen ammatti-identiteetin kulmakivi. Suomalaisten journalistin eettisten ohjeiden 27. pykälä toteaa: "Yksityiselämään kuuluvia erityisen arkaluonteisia seikkoja voi julkaista vain asianomaisen suostumuksella tai jos niillä on poikkeuksellista yhteiskunnallista merkitystä." Vakavampi asiajournalismi on kuitenkin pystynyt etiikkaansa tai professionaalisuuttaan kyseenalaistamatta lähtemään mukaan poliitikkojen intiimin elämän yksityiskohtien paljasteluun selittämällä, että korkean poliittisen vallankäyttäjän kaikki puolet ovat yhteiskunnallisesti merkittäviä. Vallan vahtikoirana median täytyy pitää silmällä onko poliitikko seonnut ja menettänyt arvostelukykynsä. Myös luonnetodistuksiin voidaan vedota: jos poliitikko tekee tällaista yksityiselämässään, niin eikö hän ole yleensäkin epäluotettava? Perusteluna voi olla myös sukupuolisen ahdistelun epäily, etenkin jos asetelma muistuttaa esimiehen ja alaisen suhdetta.

On kuitenkin huomattava, että mediajärjestelmä itse pystyy tekemään asiasta kuin asiasta yhteiskunnallisesti merkittävän. Sen jälkeen kun media on nostanut suuren kohun asiasta ja koko kansa puhuu siitä, on asiasta tullut yhteiskunnallisesti merkittävä ilmiö. Puolueen saattaa olla imagosyistä pakko päästä eroon massiivisen kielteisen mediajulkisuuden kohteesta, olipa hänet todistettu syylliseksi tai ei (esim. Jaskarin tapaus).

Viihteellistymiseen voidaan vielä soveltaa Aristoteleen (1997) Runousopissaan esittämää määritelmää tragediasta ja komediasta. Tragedia, vakava näytelmä, kertoo itseämme paremmista, ylevämmistä ihmisistä. Komedia taas kertoo meitä huonommista ihmisistä, joiden heikkouksille ja virheille voimme nauraa. Tabloidien esitystapa on tässä mielessä komediallinen. Tavallinen kansa voi nauttia siitä, että tärkeä ja korkeassa asemassa oleva poliitikko suistuu turvalleen. Klovnin roolissa toikkaroi usein "hölmö" poliitikko.

Joke Hermesin (1995) naistenlehtien lukijoita käsittelevän tutkimuksen mukaan vahingonilo on yksi lukukokemusta jäsentävä ilo. Julkkisten kurjuus sai lukijat tuntemaan oman elämänsä paremmaksi tai auttoi käsittelemään esimerkiksi turhautumisen ja surun tunteita. Lukijat tunsivat myös suoranaista vahingoniloa, jos rikkailla, kuuluisilla ja korkeassa asemassa olevilla meni huonosti. Jos hyväosaisina pidetyt julkkikset kohtasivat koettelemuksia, katsottiin eräänlaisen kosmisen oikeudenmukaisuuden toteutuvan muuten niin epäreilussa maailmassa. (Juorujulkisuudesta ks. Olander 2006). 


\section{JOURNALISMIN POPULAARIKULTTUURISTUMINEN}

Viihteellistymisen ohella poliitikkojulkisuuden muutosten voidaan katsoa liittyvän median populaarikulttuuristumiseen. Esimerkiksi Dahlgrenille ja Sparksille (1992) "populaari" merkitsee paitsi" suosittua" myös" kansaa" eliitin vastakohtana (ks. myös Hartley 1997). Perinteisesti kansa tai "rahvas" on määrittynyt kielteisesti alhaiseksi, karkeaksi ja sivistymättömäksi. Tällöin kansaa ovat määritelleet siitä erottautumishaluiset eliitin jäsenet, jotka ovat halunneet paternalistisesti sivistää kansaa omien makutottumustensa mukaisesti. Kirjoittajat näkevät muun muassa laatulehdistön ${ }^{16}$ eliitin maun mukaisena valtablokin äänitorvena ja mieltävät populaarilehdistön puolestaan edustavan kansaa, alistettuja.

Monet kulttuurintutkijat, John Fiske (1992) etunenässä, ovat puolustaneet populaarilehdistön arvoa. He kannattavat korkea- ja matalakulttuurin välisen hierarkian romuttamista ja kyseenalaistavat perinteisen vasemmistoälymystön (modernistisen) valistushenkisen informaatiouskon ja rationaalisuuden. Vasemmistonhan pitäisi tietenkin olla kansan ja populaarin puolella, eikä myötäillä eliittiä (Sparks 1992).

Tabloidit purkavat Fisken (1992) mukaan uutisten ja viihteen erottelun, samoin fakta ja fiktio sekoittuvat. ${ }^{17}$ Siinä missä laatulehdet tuudittavat uskomaan auktoriteetteihin, tabloidit kylvävät tervettä epäluuloa, kriittisyyttä ja skeptistä naurua alistettujen joukkoon. Tabloidien ratkaisemattomat yhteiskunnalliset vastakohtaisuudet, epävakaus, tiedon keskeneräisyys ja esitystavan liioittelevuus rohkaisevat yleisöä omaan merkitystuotantoon, eikä ottamaan merkityksiä valmiina "ylhäältä" eliitin suunnalta. Ei ole niinkään tärkeää, ovatko jutut totta, tärkeämpää on tabloidien vastustava asenne virallisen totuusjärjestyksen suhteen. Tabloidit ovat omiaan voimistamaan heikkojen vastarintaa alistamista vastaan. (Fisken näkemyksistä yleisemmin ks. Fiske 1989; "kulttuurisen populismin" kritiikistä ks. esim. McGuigan 1992; Fornäs 1998; Kellner 1998, 44-47 ja Stevenson 1995, 94-102).

Median tabloidisoituminen ei ole Fisken esittämistä lähtökohdista kielteinen ilmiö. Päinvastoin se on omiaan heikentämään eliitin ylivaltaa ja vahvistamaan alistettua kansaa. Tabloidisoitumisen myötä tavallisesti vaiennetut äänet pääsevät ilmoille ja demokratia vahvistuu. Populaarimedia on kaupallisesti riippuvaista kansasta ja oppinut tuottamaan rahvaan maun mukaisia kulttuurituotteita. Näistä lähtökohdista populaarilehdistön vahvistumisen voi katsoa edustavan demokraattista käännettä. Graeme Turner $(2004,82-85)$ toteaa, että viime vuosikymmen on avannut mediaan pääsyn naisille, etnisille ryhmille, vähemmistöille ja erilaisia luokka-asemia edustaville. Turnerin mielestä prosessi on kuitenkin kohdallisemmin kuvattavissa "demoottiseksi" (demotic - kansanomainen) kuin demokraattiseksi käänteeksi. Äänten moninaisuus mediassa ei vielä ole tae demokratian edistymisestä yhteiskunnassa.

Myös feministisestä näkökulmasta populaarilehdistön nousu on tarjonnut mahdollisuuksia julkisuuden demokratisoitumiselle. Ainoastaan asiantuntijat ja eliitti pääsivät ääneen laatulehdistössä, mutta populaarilehdistö antaa myös aiemmin marginalisoitujen äänien tulla esiin. Siirtymä masku- 
sallii aiemmin vaietun, kodin piirissä naisiin ja lapsiin kohdistuvien väärinkäytösten paljastumisen ja kritiikin. Henkilökohtainen on poliittista: yksityisen kautta saadaan keskusteluun monia koskettavia yhteiskunnallisia asioita (Lumby 1999); van Zoonen 2005; McKee 2005).

Populaarilehdistöä on moitittu politiikkaa trivialisoivaksi ja poliittista saippuaoopperaa rakentavaksi. Van Zoonen (2005; 2003) kuitenkin ihmettelee, miksi erityisesti naisten suosimaa genreä käytetään metaforana halventavassa mielessä. Sen sijaan, että populaaria pidettäisiin irrelevanttina tai vaarallisena demokratialle, van Zoonen (2005) korostaa populaarikulttuurin positiivisia puolia. Fanien käyttäytyminen suosikkiensa suhteen ei ole fundamentaalisesti erilaista kuin se, mitä vaaditaan aktiiviselta kansalaiselta terveessä demokratiassa. Jos kansalaisten irrallisuus, apatia ja passiivisuus ovat läntisten demokratioiden pääongelma, niin miksi emme ottaisi oppia populaarikulttuurista, jossa nämä kiinnostamattomuuden ongelmat ovat tuntemattomia?

Tämän näkemyksen vastapainoksi voidaan ottaa Karen Rossin (2002) haastattelututkimus naispoliitikoiden suhtautumisesta politiikan populaariin esittämiseen mediassa. Naispoliitikot kokivat poliittisen asian saamisen esiin mediassa vaikeaksi, koska media keskittyy yksityiselämän kiemuroihin ja palauttaa naiset hyvin usein heidän seksuaalisuuteensa:
Yleensä ottaen, naispoliitikot kaikissa kolmessa tapaustutki- muksessa suhtautuivat hyvin kielteisesti siihen, miten uutis- media on päättänyt esittää politiikan, poliittiset prosessit ja poliitikot. Politiikan koko kirjoa edustavien naisten keskuu- dessa oli laaja yksimielisyys siitä että media on muuttunut masentavan tabloidimaiseksi (...) ja että poliittiset puheet ja poliittiset kannat suodatetaan journalistisen linssin läpi mikä näyttää johtavan "dumbing down" ilmiöön kohti pienintä yhteistä ääninäytettä... (Ross 2002, 69)

Yllä mainittau ilmaus dumbing down liittyy tabloidisoitumiskeskusteluun ja se on usein suomennettu "tyhmentämiseksi". Kulttuurintutkijat pitävät ilmausta vahvasti asenteellisena.

Poliittisen viestinnän tutkija Darren G. Lilleker $(2006,69)$ toteaa kuitenkin neutraalimmin, että ilmaus viittaa "politiikan esittämistavan muotoutumiseen populaarikulttuurin esittämistavan kaltaiseksi".

Samoin kulttuurintutkijat käsittävät sanonnan "the lowest common denominator" elitistiseksi ja populaaria halventavaksi. Fiske toteaa viestinnän ja kulttuurintutkimuksen sanakirjassa (O'Sullivan ym. 1997, 171), että sanonta viittaa eliitin halveksivaan suhtautumiseen tavallisen kansan makutottumuksiin ja vaatii, ettei termiä koskaan omaksuta viestintä- ja kulttuurintutkijoiden sanastoon. "Pienin yhteinen nimittäjä" on matematiikan termi, jota käytetään myös kuvainnollisesti ilmaisemaan sitä, mikä on kaikille yhteistä. Populaarikulttuuria tuotettaessa tavoitellaan yleensä mahdollisimman laajaa asiakaskuntaa. Tällöin keskitytään sellaisiin asioihin, jotka puhuttelevat yleisinhimillisesti ketä tahansa. Elämä, kuolema, terveys, sairaus, rakkaus, seksi, tunteet ja ruumiillisuus koskettavat universaalisti kaikkia, koska ne perustuvat ihmislajin keholliseen olemukseen. 
Esimerkiksi maailman yli kulttuurirajojen valloittaneet Hollywood -elokuvat ovat keskittyneet juuri näihin ihmisenä olemisen perusmääreisiin.

Yhteisen nimittäjän etsiminen voisi tarkoittaa "alas perusteisiin" menemistä, jolloin siinä ei tarvitsisi nähdä tavallista kansaa halveksivaa sivumerkitystä. Politiikan julkkistuminen on yleensä merkinnyt politiikan asiakysymysten jäämistä syrjään ja huomion keskittymistä poliitikkojen terveyteen, romansseihin, ihmisuhdeongelmiin ja seksuaalielämään. Nämä ovat inhimillisesti kiinnostavia aiheita, koska ne tarjoavat samastumispohjaa miltei kenelle tahansa. Toisaalta julkkispohjaisiin keskusteluihin liittyy ainakin mahdollisuus yhteiskunnallisesti tärkeän keskustelun syntymiseen: yksittäisen kautta voidaan esittää yleisempää. Tämä keskustelu syntyy yleensä vasta kohun tunnekuohun vaimennettua ja deliberaation alettua.

\section{MITEN SUHTAUTUA POPULAARIKULTTUURISTUVAAN MEDIAAN?}

John Corner ja Dick Pels (2003,3-4) erottavat teoksessaan Media and the Restyling of Politics kaksi poliittisen viestinnän tutkimuksen lähestymistapaa median ja politiikan suhteeseen. Perinteisempi, "vammauttamisen näkökulma" (disabling perspective) esittää, että media heikentää demokratiaa. Tässä näkökulmassa lähdetään siitä, että asiallinen informaatio tuottaa järkeviä ja rationaaliin keskusteluun kykeneviä kansalaisia. Tabloidien "hömppä" sen sijaan täyttää kansalaisten mielet yhteiskunnallisesti merkityksettömällä trivialla. Viihdemedia tuottaa keskustelua, jossa juoruillaan vaikkapa Vanhasen uuniperunoista ja seksitavoista sen sijaan, että keskusteltaisiin vakavasti yhteisistä asioista.

Corner ja Pels edustavat uudempaa"mahdollistamisen näkökulmaa" (enabling perspective), jonka mukaan media on modernin demokratian välttämätön agentti."Vapaa lehdistö" mahdollistaa tiedon kulun, erilaisten näkemysten esiintulon ja vallankäyttäjien kriittisen tutkimisen. Tämä kaikki myös toimii politiikan terveyden ja aktiivisen kansalaisuuden takeena. Jos tässä nousee ylipäänsä esiin median vaikutus (influence), niin se nähdään optimistisesti. Siten demokratia on popularisoitumisen myötä paremminkin edistymässä kuin taantumassa. (Corner \& Pels 2003, 4).

Uusi koulukunta näyttää olevan vastareaktio vanhemmalle poliittisen viestinnän tutkimuksen koulukunnalle. Yleensäkin tieteellisten esitysten hermeneutiikassa on syytä kiinnittää huomiota siihen, mitä vastaan se suunnattu. Toisin sanoen, sen ymmärtämisessä on huomattava esitysten antiteesin luonne. Viestinnän vanhempi näkemys oli vasemmistolainen ja mediakriittinen. Kun uusi paradigma asettuu kriittiseen suhteeseen vanhaan nähden, syntyykin paradoksaalisesti kritiikin kritiikkiä. Näin saatu kanta suhtautuu julkisuuden viihteellistymiseen myönteisesti ja kritiikittömästi. 
Cornerin ja Pelsin teoksen (2003) diskurssista on tulkintani mukaan hieman kärjistäen erotettavissa seuraavat vastakohta-asetelmat:

\begin{tabular}{|c|c|c|}
\hline Vanha koulukunta & vs. & Uusi koulukunta \\
\hline Informaatiosisältö & vs. & Muoto, tyyli \\
\hline Mitä sanotaan & vs. & Miten sanotaan \\
\hline Tiede & vs. & Taide \\
\hline Todellinen & vs. & Tekstuaalinen \\
\hline Etiikka & vs. & Estetiikka \\
\hline Järki (valistus) & vs. & Tunne (romantiikka) \\
\hline Velvollisuudet & vs. & Vapaudet \\
\hline Kommunitarianismi & vs. & Libertarianismi \\
\hline Sosialismi & vs. & Fasismi (josta paljon opittavaa) \\
\hline Valtio on hyvä (Hegel) & vs. & Valtio on paha (liberalismi) \\
\hline Valtio edustaa yleisiä intressejä & vs. & Valtio edustaa vallanpitäjiä \\
\hline Sääntely pitää markkinat terveinä & vs. & Sääntely on markkinahäiriö \\
\hline Asiajournalismi takaa demokratian & vs. & "Laatujournalismi" tukee elitismiä \\
\hline Tabloidit tuhoavat demokratiaa & vs. & Tabloid -journalismi parantaa demokratiaa \\
\hline Kaupallisuus pahasta & vs. & Kaupallisuus OK \\
\hline Kriittistä viihdeteollisuudelle & vs. & Epäkriittistä viihdeteollisuudelle \\
\hline Tutkija asemoituu kasvattajaksi & vs. & Tutkija asemoituu kuluttajaksi, faniksi \\
\hline Informoidun kansalaisuuden puolesta & vs. & Marginalisoitujen puolesta \\
\hline
\end{tabular}

Uusi lähestymistapa on lähes antiteesi vanhempaan mediakriittiseen paradigmaan nähden. On tietysti hyvä, jos uusi koulukunta kehottaa soveltamaan tutkimukseen uusia näkökulmia. Mutta tämän ei pitäisi tarkoittaa, että muut näkökulmat ovat yhtäkkiä muuttuneet kelvottomiksi.

Nähdäkseni Cornerin ja Pelsin teoksen edustama poliittisen viestinnän näkökanta menee vanhaan kantaan nähden toiseen ääripäähän havaitessaan populaarikulttuuristumisessa ainoastaan myönteisiä mahdollisuuksia. Populistinen myönteisyys voi merkitä mediakritiikistä luopumista, vallitsevan ideologian hyväksymistä ja eettisyyden korvautumista makuasioilla. Populistinen myönteisyys voi kertoa enemmän akateemisen tutkimuksen vastakkaisuuksien kautta kehittyvästä (dialektisesta) luonteesta kuin sosiaalisesta todellisuudesta (vrt. McGuigan 1992, 171-172).

Juha Herkman on todennut, että kulttuurintutkimuksen on otettava vakavasti ne historialliset ja materiaaliset olosuhteet, joiden rajoissa kulttuuri merkityksellistyy:

Mikäli näin ei tapahdu, kulttuurintutkimus toistaa markkinaliberalistista eetosta tukevia hokemia yleisön mauista, kulutuksen mielihyvästä, yhteisöllisyydestä ja identiteettipolitiikasta. Kulttuurintutkimuksen kriittisyys pelkistyy ontoksi itsestäänselvyydeksi, jonka nykykulttuurin kaupallisuus, yksilökeskeisyys ja mielihyvähakuisuus syleilevät kuoliaaksi. (Herkman 2006, 29) 
Kulttuurintutkimuksen oma asema tutkimuksen kentässä on paradoksaalinen. Aiemmin itsekin tieteen marginaaliin lukeutunut kulttuurintutkimus kritisoi hegemonisia diskursseja ja vallassaolijoita ja puhuu marginalisoitujen puolesta. Nyt kulttuurintutkimus on kuitenkin noussut yhteiskuntatieteissä merkittävään asemaan. Kulttuurintutkimusta on siten paikallaan reflektoida kriittisesti. Omat huomautukseni on tarkoitettu Jim McGuiganin (1992) tapaan sympaattiseksi kritiikiksi. Pontimenani on se, että kun tieteellisten näkemysten heiluriliike vie kovin kauas johonkin suuntaan, on paikallaan tehdä korjausliikettä takaisinpäin.

\section{KRIITTISIÄ HUOMAUTUKSIA POSTMODERNISMISTA}

Nostan vielä lopuksi esiin muutamia uudempaan poliittiseen viestintään liittyviä kriittisiä näkökohtia. Ensimmäinen huomautus koskee anglosaksisen liberalismin ja saksalaisen poliittisen filosofian perinteen (Kant, Hegel, Marx, Snellman) vastakohtaisuutta ${ }^{18}$. Kuten Tuija Pulkkinen (2003) analysoi, on liberalismin perustana vapaan liikkeen metafora. Valta on kykyä estää tai rajoittaa toisen vapaata liikettä. Näin valta on siis vapauden vastakäsite ja olemukseltaan jotakin ei-toivottavaa. Liberalismin tavoitteena onkin päästä eroon kaikesta vallasta tai ainakin supistaa vallankäyttö minimiinsä. Valtio "vallanpitäjineen" (poliitikot) on jo lähtökohtaisesti paha ja jatkuvasti epäiltävä asia. Tästä on suoraan johdettavissa median rooli vallanpitäjien vahtikoirana. Kasvattajan paternalistinen asenne on liberalismille vastenmielinen, ihminenhän ymmärretään kypsän aikuiseksi valintojen tekijäksi.

Cornerin ja Pelsin edustama poliittisen viestinnän koulukunta näyttää tulleen "ympäri käydään ja yhteen tullaan" -periaatteella lähelle perinteistä liberalismin näkemystä. Anglosaksiseen kulttuuriin syntyneelle tämä on pikemminkin luonnollinen, reflektoimaton ideologinen valinta kuin uudenaikainen ratkaisu. Voi olla, että tähän näkemykseen päädytään hegeliläisen perinteen vastustamisen kautta ja näin pudotaan liberalismin, jopa uusliberalismin syliin. Liberalismin diskurssit ovat nykyisin länsimaissa hegemonisessa asemassa. Sen sijaan että myötäillään nyky-yhteiskunnan voimakkaimpia diskursseja, tutkimuksen olisi syytä omaksua ideologiakriittinen asenne, josta kulttuurintutkimuksen piirissä esimerkin tarjoavat vaikkapa Johan Fornäs (1998) ja Douglas Kellner (1998). Eräässä mielessä postmodernistinen poliittisen viestinnän teoria on "voittajan historiaa": nyt yhteiskunnassa vallitseva diskurssi määrää tutkijoidenkin ajatukset. Esimerkiksi viihteen ja pelien kohdalla nuorison fani-kuluttajadiskurssi on nykyään yhteiskunnassa dominoivampi kuin vanhempien kasvattajadiskurssi.

Saksalaisessa perinteessä vapaus on liberalismista poiketen yhteisön kykyä hallita itseään ja säätää toiminnalleen järkevät lait (Pulkkinen 2003; myös Karvonen 2008). Politiikka on yhteisen hyvän edistämistä, ja valtio on yleishyödyllisen kestävän kehityksen takaaja. Kasvattajuus tulkitaan pelkästään myönteiseksi asiaksi. Talouden (ja kaupallisen journalismin) puolestaan nähdään edistävän lyhytnäköisesti yritysten omaa etua ja tuottavan hallitsemattomia, ei-toivottuja ulkoisvaikutuksia (vrt. Paloheimo $\&$ 
tuotteena rapauttaneeksi demokratiaa. Vaikka saksalainen perinne ei olekaan muodissa, sitä ei tarvitse pitää vanhanaikaisena tai kelvottomana. ${ }^{19}$

Toiseksi, "fiskeläisessä" kultuurintutkimuksessa voi muutenkin olla anglosaksista vinoumaa. Colin Sparks $(1992,37)$ toteaa, että brittiläisessä lehdistössä laatulehdistön ja populaarin lehdistön välillä on yhtä suuri ero kuin Bachilla ja Motörheadilla. Asetelma on ollut polarisoitunut siten, että vakava populaari "keskilehdistö" puuttuu. Samoin luokka-asetelmat ovat olleet Britanniassa jyrkät. Jos hyväksytään, että media ei vain kuvaa luokkia vaan myös tuottaa niitä, The Sunin ja muun keltaisen lehdistön voi katsoa sivutuotteenaan myös pitäneen työväenluokkaa alisteisessa asemassa.

Suomessa ja yleensäkin Pohjoismaissa lehdistö sen paremmin kuin sosiaaliluokatkaan eivät ole olleet yhtä polarisoituneita kuin Iso-Britanniassa, joten Britanniaa koskevan analyysin soveltaminen suomalaiseen yhteiskuntaan on ongelmallista. Täällä media kierrättää lähinnä keskiluokan näkemyksiä, ja kaiken lisäksi suurin osa kansasta katsoo kuuluvansa keskiluokkaan. Anglosaksinen poliittinen järjestelmäkin on sellainen, että se suosii PR-valtion ja poliittisten spin doctoreiden syntymistä. Kaksipuoluejärjestelmässä voittaneen puolueen vaalimarkkinointikoneisto siirtyy hallitusvallan propagandakoneistoksi ja aiheuttaa erityisen kireän suhteen journalisteihin. Suomen monipuoluehallituksissa ilmiö jää paljon heikommaksi.

Kolmanneksi, estetiikka ja emotionaalisuus ovat epäilemättä trendejä nykyisessä kaupallisessa kulttuurissa, kuten mainoksissa. Mutta täytyykö yhteiskuntatutkimuksenkin omaksua nämä vallitsevat ajatusmuodot ja mennä mukaan juhlimaan näitä piirteitä? Politiikassa äärioikeisto on ollut vahva juuri esteettisessä ja tunteisiin vetoavassa politiikassa. Nyt äärioikeisto on nouseva voima esimerkiksi Itävallassa, Hitlerin kotimaassa. Ehkä yhteiskuntatutkimuksen suopealla nyökyttelyllä populismin suuntaan on lopulta vaarallisia vaikutuksia. Pohjimmiltaan järkiperäisenä käytäntönä tieteen ei ehkä kannattaisi oman etunsakaan nimissä kovin juhlia tunteen paloa, yksinkertaistuksia ja syntipukkien etsintää.

Postmodernissa teoriassa estetiikan korostus nousee sen lähtökohtana olevasta taiteen ja kirjallisuuden tutkimuksesta. Tästä lähtökohdasta käsin nähdään lopulta kaikki muukin todellisuus taiteen metaforan läpi. Taide on olennaisesti estetiikkaa, se on makuasia. Tärkeintä siinä on tyyli ja omaperäisyys sekä poikkeavuus esittämisen normeista. Taidetta ei arvioida informaatioarvon perustella kuten journalismia. Näin ajateltuna se, lukeeko Seiskaa vai Helsingin Sanomia, on puhtaasti makuasia, josta on turha kiistellä. Mutta onko oikein verrata asiajournalismia yläluokkaiseen taiteeseen? Musiikki ehkä on makuasia, mutta journalismi on muutakin. Sitä voi verrata vaikkapa kouluun: ei ole ihan makuasia, opetetaanko koulussa lapsille pätevä ja asiallinen kuva maailmasta, vai keskitytäänkö siellä vain käymään läpi julkkisten seksielämää. Journalismilla on yhä informatiivinen funktionsa.

Neljänneksi tartun vielä Cornerin ja Pelsin $(2003,4)$ huomautukseen, "...jos kysymys median 'vaikutuksista' ylipäänsä nousee esiin, se nostetaan esiin tavalla joka korostaa median potentiaalia hyvän tekemiseen". Juuri tähän tapaan nykypäivän hallitsevissa diskursseissa kehotetaan aina näkemään muutoksissa ongelmien sijaan mahdollisuuksia ja haasteita. Viestinnän vaikutus ei sen sijaan kuulu nykymuodin mukaiseen viestinnän tutkimukseen. Etnografisen käänteen myötä vaikutustutkimuksen kysymys, 
"mitä media tekee ihmisille", on pois suljettu, ja tilalle on tullut päinvastainen kysymys, "mitä ihmiset tekevät medialla". Tästä näkökulmasta median vaikutukset eivät tematisoidu, niitä ei edes kuulu kysyä. Jos vaikutuksia ei tunnusteta olevan olemassakaan, on kai jokseenkin samantekevää, millaisena journalismi maailman esittää.

Kuitenkin esimerkiksi retoriikan tutkimuksen lähtökohtana on juuri ihmisiin vaikuttaminen. Markkinoinnin ohella mediaretoriikka vaikuttaa ihmisiin, vakuuttaa heidät jostakin, suostuttelee heidät ajattelemaan ja tuntemaan esimerkiksi politiikasta tietyllä tavalla. Miksi mainostajat tuhlaisivat miljardeja mainontaan, jos tällä viestinnällä ei olisi toivottua vaikutusta? Yhteisö- ja markkinointiviestinnän ammattilaisille viestinnän vaikuttavuuden arvioiminen ja mittaaminen on jatkuvaa rutiinia ja suuri kiinnostuksen aihe. Myös sosiaalisen konstruktivismin pohjalta jonkinlainen vaikuttavuus on selvä asia. Millaiseksi maailma (tässä tapauksessa politiikka) esityksissä konstruoidaan, sellaista yhteistä todellisuutta myös rakennetaan.

Yhteisen todellisuuden tuottamisesta on syytä huomata, että representaatioilla on aina sekä olemassa olevaa todellisuutta kuvaava puolensa että "tulevaista" sosiaalista todellisuutta luova puolensa (Karvonen 2003; 2004; 2005). Ei siis tule keskittyä dikotomisesti jompaankumpaan ulottuvuuteen, vaan on syytä nähdä mediaesitykset Anthony Giddensin (1984) viitoittamaan tapaan dualiteettina, kaksipuolisuutena. Media sekä kuvaa todellisuutta että vaikuttaa todellisuuteen. Ihmiset sekä tuottavat aktiivisesti merkityksiä mediaesityksistä että heitä tuotetaan retorisesti (suostutellaan, vakuutetaan) mediaesityksillä.

Modernin postmodernin teorian jälkeen jään odottamaan seuraavaa, nämä ylittävää teorian vaihetta.

Tekijä kiittää teemanumeron toimitusta ja nimettömiä arvioijia poikkeuksellisen paneutuvasta ja huolellisesta toimitustyöstä.

Viitteet

1 Ymmärtäminen nähdään tässä hermeneuttisesti dialogina, joka tähtää monipuolisen, monimääreisen ja eri intressit huomioivan käsityksen luomiseen yleensä lähtökohtana olevan yksipuolisen ymmärryksen sijaan. Esim. Gadamer 2004, 29-39.

2 Olen käsitellyt viihteellistyvän politiikkojulkisuuden teemaa ja näitä tapauksia myös kirja-artikkelissani Karvonen (2009) sekä konferenssiesitelmäni Karvonen (2007c).

3 En kuitenkaan lähesty aihepiiriä skandaalien näkökulmasta kuten Pasi Kivioja (2008b) valmisteilla olevassa väitöskirjassaan.

4 "Hömppä" on vanhaa toimittajasanastoa.

5 Helsingin Sanomien politiikantoimittajakonkari Unto Hämäläinen totesi Susanna Ruususen Pääministerin morsian -kirjan kansien julkistustilaisuudessa 6.2.2007 YLEn tv-uutisille: "Vähän hävettää olla täällä". Paikalla tungeksi 50 valokuvaajaa ja toimittajaa. Tilaisuudessa julkistettiin vain kirjan kannet kuvineen. Unto Hämäläisen vaaliblogi "Perässähiihtäjä" http://blogit.hs.fi/unski/tiistai-62200723merkinta/.

6 Pääministeri Matti Vanhanen tosin käräjöi tätä tulkintaa vastaan. Juttu on hovioikeuden pohdittavana ja voi mennä korkeimpaan oikeuteen asti. Vanhasen mielestä tapauksessa vedetään rajaa sille, millä tavoin poliitikkojen yksityiselämää voi Suomessa tiedotusvälineissä ja kirjoissa esitellä. 
7 Olen itse yrittänyt edetä tällä saralla aiemmin kehittämällä niin sanotun perspektiivisen realismin näkökantaa, jossa ylitetään vanhan realismin (moderni) ja konstruktivismin (postmoderni) rajoittuneet alkuoletukset. (Karvonen 1997, 47-48; 1999a, 91-98; 1999b).

8 Hollywoodin ja Washingtonin juoruilla itsensä elättänyt Matt Drudge perusti vuonna 1994 viikottaisen tilattavan sähköpostikirjeen, ja 1997 hän siirsi palvelunsa internetiin. Palvelu koostuu etupäässä linkeistä muualla julkaistuihin juttuihin, mutta sivuilla on myös omia paljastusreportaaseja. Ks. http://en.wikipedia.org/wiki/Drudge_Report

9 Esimerkiksi näköalapaikalta median kehitystä seurannut A.-P. Pietilä $(2007,207)$ toteaa, että amerikkalaiset kehitysilmiöt ovat yleensä tulleet Suomeen Ruotsin markkinoiden kautta parin vuoden viiveellä.

10 Mediaväki vetoaa mieluusti sananparteen "Turha syyttää peiliä, jos naama näyttää vinolta". Eli turha syyttää mediaa neutraalina peilinä, sillä vika on esim. poliitikossa itsessään. Jos media ymmärretään epäsuhteisesti korostavaksi pilailupeiliksi, tältä argumentilta putoaa pohja.

11 Tosin "poliittisella teatterilla" on pitkä historia, muistaen vaikkapa Niccolo Machiavellin (1984) opetuksia Ruhtinas -teoksessaan 1500-luvulla ja Jürgen Habermasin (2004) esitystä keskiaikaisesta näyttäytymisjulkisuudesta.

12 Hannu Lehtilä (2005): "Tarja Halonen - yksi meistä".

13 Oxford English Dictionary. Elekroninen versio.

14 Neil Postman (1987) on esittänyt, että julkinen keskustelu Yhdysvalloissa on saamassa viihteen muodon televisiokulttuurin vuoksi. Postmanin ajatuksiin viitataan usein kriittisesti modernin teorian ilmentyminä, mutta yleensä ei noteerata sitä, että hän edustaa ajattelussaan varsin vahvaa teknologista determinismiä.

15 Fenomenologinen intentionaalisuuden käsite viittaa tietynlaiseen suuntautumiseen kohti maailmaa. Tästä laajemmin Karvonen 1992.

16 "Laatujournalismin" käsite on syytä problematisoida perinpohjaisesti Eeva Mäntymäen (2006) tapaan. Ei ole syytä ajatella, että jokin esitysgenre on laadukasta ja toinen taas ei. Sen sijaan Mäntymäki kannattaa yleisradiotoiminnan yhteydessä prosessuaalista laatuajattelua, jossa laatua arvioidaan vaikuttavuuden näkökulmasta. Missä märin ohjelmat edistävät sovittuja tavoitteita kuten kansalaisuuteen kannustamista.

17 Fiske $(1992,48)$ viittaa tässä ennen muuta amerikkalaisiin supermarket-tabloideihin, joissa seikkailevat ufot ja humanoiditkin.

18 Suomalaisen journalismin liberalistisia ja hegeliläisiä juonteita ovat käsitelleet Heikki Heikkilä (2001) ja Eeva Mäntymäki (2006) väitöskirjoissaan.

19 Saksalaisella perinteellä on omat ongelmansa: mm. rationalismi, yksiäänisyys ja autoritaarisuus (Pulkkinen 2003). Liberalismin ja saksalaisen perinteen kritiikistä ks. Karvonen 2007b. Huomautettakoon, että niin postmodernin kriitikkona kuin tässä esiinnynkin, Pulkkisen (2003) esittämä versio postmodernista teoriasta on monessa suhteessa kannatettava.

\section{Kirjallisuus:}

Alho, Arja (2004) Silent Democracy, Noisy Media. Academic Dissertation, June 2004. University of Helsinki, Faculty of Social Sciences, Department of Sociology. http://ethesis.helsinki.fi/julkaisut/val/sosio/vk/alho/silentde.pdf

Aristoteles (1997) Retoriikka ja runousoppi. Helsinki: Gaudeamus

Aslama, Minna (2005) Tietoisku, tarina vai nähtävyys? Suomalaisen televisiojournalismin moodeista. Tiedotustutkimus 28:4-5, 55-71.

Asp, Kent \& Peter Esaiasson (1996) The Modernization of Swedish Campaigns. Teoksessa: D. L. Swanson \& P. Mancini (toim.) Media and Modern Democracy. Westport, CT: Praeger, 73-90.

Aula, Maria-Kaisa (1991) Poliitikkojen ja toimittajien suhteet murroksessa? Tutkimus Yleisradion politiikan toimittajien ammatti-identiteetistä 1980-luvulla. Tutkimusraportti 5/1991. Helsinki: Oy Yleisradio Ab, Tutkimus- ja kehitysosasto.

Beacon, David (2004) Politicians, Privacy, and Media Intrusion in Britain. Parliamentary Affairs 57:1, 9-23.

Betti, Emilio (2005) Hermeneutiikka hengentieteiden yleisenä menetelmäoppina. Teoksessa Tontti, Jaakko (toim.) Tulkinnasta toiseen. Esseitä hermeneutiikasta. Tampere: Vastapaino. 108-129. 
Boorstin, Daniel J. (1962) The Image. Or What Happened to the American Dream. New York: Atheneum.

Carpentier, Nico (2005) Identity, Contingency and Rigidity. The (counter-)hegemonic Constructions of the Identity of the Media Professional. Journalism 6:2, 199-219.

Corner, John \& Dick Pels (2003) Introduction: The Re-styling of Politics. Teoksessa Corner, John \& Dick Pels (toim.) Media and the Restyling of Politics. Consumerism, Celebrity and Cynicism. London, Thousand Oaks \& New Delhi: Sage Publications, $1-18$.

Dahlgren, Peter \& Colin Sparks (1992) (toim.) Journalism and Popular Culture. London: Sage.

Dahlgren, Peter (1992) Introduction. Teoksessa Dahlgren, Peter \& Colin Sparks (toim.) Journalism and Popular Culture. London: Sage, 1-23.

Davenport, T. H., \& J. C. Beck (2001) The Attention Economy. Understanding the New Currency of Business. Harvard: Harvard Business School.

Drudge Report. Wikipedia-artikkeli tästä uutispalvelusta. http://en.wikipedia.org/ wiki/Drudge_Report

Ekström, Mats (2000) Information, Storytelling and Attractions: TV Journalism in Three Modes of Communication. Media, Culture \& Society 22:4, 465 - 492.

Entman, Robert M. (1991) Framing U.S. Coverage of International News: Contrasts in Narratives of the KAL and Iran Air Incidents. Journal of Communication 41:4, Autumn.

Entman, Robert M. (1993) Framing: Toward Clarification of a Fractured Paradigm. Journal of Communication 43(1993):4, Autumn.

Fiske, John (1989) Understanding Popular Culture. Boston: Unwin Hyman.

Fiske, John (1992) Popularity and the Politics of Information. Teoksessa Dahlgren, Peter \& Colin Sparks (toim.) Journalism and Popular Culture. London: Sage, 45-63.

Fornäs, Johan (1998) Kulttuuriteoria: myöhäismodernin ulottuvuuksia. Suomennoksen toimittanut Mikko Lehtonen. Tampere: Vastapaino.

Gadamer, Hans-Georg (2004) Hermeneutiikka. Ymmärtäminen tieteissä ja filosofiassa. Valikoinut ja suomentanut Ismo Nikander. Tampere: Vastapaino.

Giddens, Anthony (1984) Yhteiskuntateorian keskeisiä ongelmia: toiminnan, rakenteen ja ristiriidan käsitteet yhteiskunta-analyysissä. Suom. Pasi Andersson ja Ilkka Heiskanen. Helsinki: Otava.

Giles, David (2000) Illusions of Immortality. A Psychology of Fame and Celebrity. London: Macmillan.

Glynn, Kevin (2000) Tabloid Culture: Trash Taste, Popular Power, and the Transformation of American Television. Durham: Duke University Press, 2000.

Habermas, Jürgen (2004) Julkisuuden rakennemuutos. Tutkimus yhdestä kansalaisyhteiskunnan kategoriasta. Suom. Veikko Pietilä. Tampere: Vastapaino.

Hartley, John (1997) Popular / popular culture. Teoksessa: O’Sullivan, Tim; John Hartley; Danny Saunders; Martin Montgomery \& John Fiske (toim.) Key Concepts in Communication and Cultural Studies. Second edition. London and New York: Routledge, 231-234.

Heikkilä, Heikki (2001) Ohut ja vankka journalismi. Kansalaisuus suomalaisen uutisjournalismin käytännöissä. Tampere: Tampereen yliopisto. (Acta electronica Universitatis Tamperensis, ISSN 1456-954X; 127)

Hemánus, Pertti \& Ilkka Tervonen (1980) Objektiivinen joukkotiedotus. Helsinki: Otava.

Herkman, Juha (2006) Kriittinen kulttuurintutkimus valinkauhassa. Teoksessa Herkman, Juha ym. (toim.) Tutkimusten maailma. Suomalaista kulttuurintutkimusta kartoittamassa. Jyväskylä: Nykykulttuurin tutkimuskeskus, 21-32.

Hermes, Joke (1995) Reading Women's Magazines: An Analysis of Everyday Media Use. Cambridge: Polity Press.

Hietala, Veijo (2007) Media ja suuret tunteet. Johdatusta 2000-luvun uusromantiikkaan. Helsinki: BTJ-kustannus.

Hämäläinen, Unto (2007) "Perässähiihtäjä" blogi. http://blogit.hs.fi/unski/tiistai62200723 merkinta

Jääsaari, Johanna (2004) YLE yleisön ehdoilla?: Tutkimus suomalaisten television nykytilaa ja tulevaisuutta koskevista arvostuksista. YLE Yleisötutkimus. Tutkimuksia 5/2004. Helsinki: YLE Yleisötutkimus. 
Karvonen, Erkki (1988) Uro(s)tekojen anatomiaa. Sankaruuden tuottamisesta seikkailukertomuksissa. Tiedotustutkimus 11:2, 33-44.

Karvonen, Erkki (1991a) Representaation politiikka ja sukupuolen tuotanto. Sosiologia $28: 1$.

Karvonen, Erkki (1991b) Populaarikulttuuri elämänhallinnan tuottajana. Tiedotustutkimus 14:1.

Karvonen, Erkki (1992) Odotuksen struktuurit ja populaari representaatio. Fenomenologinen tutkielma sosiaalisista odotuksista ja niiden suhteesta populaarikulttuuriseen esittämiseen. Tampereen yliopisto, tiedotusopin laitos. Julkaisuja sarja A 80. Tampere 1992.

Karvonen, Erkki (1993) Koplataan, koplataan! Eräs muotoilu artikulaatioteoriasta. Tiedotustutkimus 16:3.

Karvonen, Erkki (1995) Ajattele positiivisesti - ota Kummeli! eli Kuinka Kummelin kanssa tehtiin mukavuustyötä. Tiedotustutkimus 18:1.

Karvonen, Erkki (1997) Imagologia. Imagon teorioiden esittelyä, analyysiä, kritiikkiä. Acta Universitatis Tamperensis 544. Tampere yliopisto, Tampere 1997. Myös elektronisena aineistona: http://acta.uta.fi/pdf/978-951-44-7393-7.pdf

Karvonen, Erkki (1999a) Elämää mielikuvayhteiskunnassa. Imago ja maine menestystekijöinä myöhäismodernissa maailmassa. Helsinki: Gaudeamus.

Karvonen, Erkki (1999b) Perspektiivinen realismi parempi - perusta kansalaisjournalismille. Tiedotustutkimus 22:2, 44-59

Karvonen, Erkki (2000a) Kaupallisuus journalismietiikan uhkana. Niin \& Näin 2000: 4.

Karvonen, Erkki (2000b) Tulkintakehys (frame) ja kehystäminen. Tiedotustutkimus 2000: 2. Myös verkossa: http://www.uta.fi/ tierka/Tulkintakehys.pdf

Karvonen, Erkki (2003) Merkitystä ei saisi irrottaa toiminnasta. Pyydetty kommenttipuheenvuoro Kauko Pietilän kirjoitukseen. Tiedotustutkimus 2003: 4-5.

Karvonen, Erkki (2004) Koko maailmako elämyspuistoksi? Simuloitujen maailmojen tuottamisen kysymyksiä. Teoksessa Kupiainen, Jari \& Katja Laitinen (toim.):

Kulttuurinen sisältötuotanto? Helsinki: Edita, 59-79.

Karvonen, Erkki (2005) Tietoyhteiskunnan mielikuvat ja todellisuus. Teoksessa Inkinen, Tommi; Antti Kasvio \& Hanna Liikala (toim.): Tietoyhteiskunta: myytit ja todellisuus. Tampere: Tampere University Press (TUP), 21-41.

Karvonen, Erkki (2007a) Halosen ja Niinistön imagonrakennus. Kampanjaretoriikan analyysi. Teoksessa Isotalus, Pekka $\&$ Sami Borg (toim.) Presidentinvaalit 2006. Helsinki: WSOY, 115-136.

Karvonen, Erkki (2007b) Kaksi oppia sananvapaudesta. Aamulehti 25.10.2007. Myös: http://www.uta.fi/ tierka/postmpulkkinen.htm

Karvonen, Erkki (2007c) Celebritisation of Politics in Finland, Esitelmä: Nordic Conference for Media and Communication Research, Helsinki 16.-19.8.2007.

Karvonen, Erkki (2008) Riippumaton toimittaja! Teoksessa Pekka Aula (toim.) Kivi vai katedraali? Organisaatioviestintä teoriasta käytäntöön. Helsinki: Infor. 114-137.

Karvonen, Erkki (2009, tulossa) Entertainmentisation of the European Public Sphere and Politics. Teoksessa Wessels, Bridgette $\&$ Jackie Harrison (toim.): Mediating Europe: New Media, Mass Communications and the European Public Sphere. New York and Oxford: Berghahn Books.

Kellner, Douglas (1998) Mediakulttuuri. Suomennos: Riitta Oittinen ja työryhmä. Tampere: Vastapaino.

Kivioja, Pasi (2004) Alaston lööppi. Millaiset uutiset myyvät tabloid-lehtiä - ja miksi? Lähitarkastelussa Ilta-Sanomien lööpit, etusivut ja myyntiluvut vuonna 2002.

Kivioja, Pasi (2008a) Iltapäivälehdet mediakentän ja yhteiskunnan muutoksessa. Tampere: Journalismin tutkimusyksikkö, tiedotusopin laitos, Tampereen yliopisto.

Kivioja, Pasi (2008b) Kiss and Sell. Näin tuotetaan täydellinen skandaali. Jaakkola, Maarit (toim.): Journalismikritiikin vuosikirja 2008, 91-101.

Koivunen, Anu (2008) Affektin paluu? Tunneongelma suomalaisessa mediatutkimuksessa. Tiedotustutkimus 31:3, 5-24.

Koivunen, Anu \& Mikko Lehtonen (2005) "Joskus on kiva olla vähemmän aikuinen". Kulttuurisen määrittelyvallan siirtymät ja julkisen puhuttelun areenat. Tiedotustutkimus 28:2, 4-27. 
Kurtz, Howard (1994) Media Circus. The Trouble with America's Newspapers. New York: Random House.

Lehtilä, Hannu (2005) Tarja Halonen - yksi meistä. Helsinki: Otava.

Lilleker, Darren G. (2006) Key Concepts in Political Communication. London etc.: Sage.

Lumby, Catharine (1999) Gotcha: Life in a Tabloid World. St. Leonards, N.S.W: Allen \& Unwin.

Luostarinen, Heikki (1994) Mielen kersantit. Julkisuuden hallinta ja journalistiset vastastrategiat sotilaallisissa konflikteissa. Helsinki: Hanki ja jää.

Luostarinen, Heikki \& Turo Uskali (2004). Suomalainen journalismi ja yhteiskunnan muutos 1980-2000. Sitra 2004. http://www.sitra.fi/julkaisut/Heiskala.pdf.

Machiavelli, Niccolo (1984) Ruhtinas. Suom. Aarre Huhtala. [Il principe]. Helsinki: WSOY.

McCombs, Maxell (2004) Setting the Agenda. The Mass Media and Public Opinion. Cambridge: Polity Press.

McCombs Maxell E. \& Donald L. Shaw (1972) The Agenda-Setting Function of Mass Media. Public Opinion Quarterly, 36, 176-187

McGuigan, Jim (1992) Cultural Populism. London and New York: Routledge.

McKee, Alan (2005) The Public Sphere: An Introduction. Cambridge: Cambridge University Press.

Meyer, Thomas (2002) Media Democracy. How the Media Colonize Politics (with Lew Hinchman). Cambridge: Polity.

Moring, Tom (2008) Media and Politics in Finland. Teoksessa Strömbäck, Jesper; Mark Ørsten $\&$ Toril Aalberg (toim.) Communicating Politics. Political Communication in the Nordic Countries. Göteborg: Nordicom, University of Gothenburg. 45-62.

Moring, Tom \& Hal Himmelstein (1993) Politiikkaa riisuttuna. Kampanjakulttuuri murroksessa televisioidun politiikan aikaan. Tutkimusraportti 6/1993. Helsinki: Yleisradio.

Mäntymäki, Eeva (2006) Hyvinvointivaltio eetterissä: Yleisradion rakentuminen populaarien diskurssien kentillä. Tampere: Tampere University Press. http://acta.uta. fi/pdf/951-44-6661-6.pdf

Olander, Ilkka (2006) Juoruava julkisuus - demokraattinen debatti? Lähitarkastelussa iltapäivälehdistön henkilöivä retoriikka. Pro gradu -tutkielma. Helsinki: Helsingin yliopisto, Valtiotieteellinen tiedekunta, Sosiaali- ja kulttuuriantropologian laitos

Olkinuora, Hannu (2006) Minne menet media? EVA. http://www.eva.fi/files/1603_ minne_menet_media.pdf

Ollila, Maija-Riitta (2005) Persoonan valta. Helsinki: WSOY.

Ollila, Maija-Riitta (2006) Luonnetestejä vai savuverhoja: yksityisyys mediassa. Teoksessa Ruusunoksa, Laura (toim.): Journalismikritiikin vuosikirja 2006, 28-36.

O'Sullivan, Tim; John Hartley; Danny Saunders \& John Fiske (1997) Key Concepts in Communication and Cultural Studies. Second edition. London and New York: Routledge.

Oxford English Dictionary. Elektroninen versio.

Paloheimo, Heikki \& Matti Wiberg (1997) Politiikan perusteet. Helsinki: WSOY.

Palokangas, Teemu (2007) The Public Service Entertainment Mission. From Historic Periphery to Contemporary Core. Teoksessa Greg Lowe ym. (toim.) From Public Service Broadcasting to Public Service Media. Göteborgः Nordicom, 119-132.

Parliamentary Affairs. Teemanumero: Public Images, Private Lives: the Mediation of Politicians Around the Globe. 57:1, January 2004.

Pernaa, Ville; Ville Pitkänen \& Erkka Railo (2006) Politiikan peleistä mediapeleihin. Teoksessa: Pernaa, Ville \& Ville Pitkänen (toim.) Poliitikot taistelivat, media kertoo. Suomalaisen politiikan mediapelejä 1981-2006. Helsinki: Ajatus kirjat. 272-281.

Pietilä, A.-P. (2007) Uutisista viihdettä, viihteestä uutisia. Median muodonmuutos. Helsinki: Art House.

Postman, Neil (1987) Huvitamme itsemme hengiltä. Julkinen keskustelu viihteen aikakaudella. Porvoo, Helsinki, Juva: WSOY.

Pulkkinen, Tuija (2003) Postmoderni politiikan filosofia. Helsinki: Gaudeamus. 2. painos.

Ramonet, Ignacio (2001) Median tyrannia. Suom. Jouni Kuurne. Helsinki: WSOY. 
Richards, Barry (2004) The Emotional Deficit in Political Communication. Political Communication, 21:339-352, 2004.

Ross, Karen (2002). Women, Politics, Media. Uneasy Relations in Comparative Perspective. Cresskill, N.J.: Hampton Press.

Schudson, Michael (1997) Why Conversation is Not the Soul of Democracy. Critical Studies in Mass Communication 14, December 1997.

Snell, Sunna; Anna Lahelma \& Pilvi Toppinen (2003) Parempia ohjelmia. TV-ohjelmatestien satoa 2001-2003. Helsinki: Yleisradio.

Sparks, Colin (1992) Popular Journalism: Theories and Practice. Teoksessa Dahlgren, Peter \& Colin Sparks (toim.) Journalism and Popular Culture. London etc.: Sage, 24-44.

Stanyer, James \& Dominic Wring (2004) Public Images, Private Lives: An Introduction. Parliamentary Affairs 57:1,1-8.

Stevenson, Nick (1995) Understanding Media Cultures. Social Theory and Mass Communication. London etc.: Sage.

Street, John (2003) The Celebrity Politician: Political Style and Popular Culture. Teoksessa Corner, John \& Dick Pels (toim.) Media and the Restyling of Politics. Consumerism, Celebrity and Cynicism. London, Thousand Oaks \& New Delhi: Sage Publications, 85-98.

Street, John (2004). Celebrity Politicians: Popular Culture and Political Representation. The British Journal of Politics \& International Relations: 2004 Vol 6, 435-452.

Suhonen, Pertti (1994) Mediat, me ja ympäristö. Helsinki: Hanki ja Jää.

Turner, Graeme (1999) 'Tabloidization, Journalism and Possibility of Critique'. International Journal of Cultural Studies 2:1.59-76.

Turner, Graeme (2004) Understanding Celebrity. London: Sage.

Uimonen, Risto (1992) Julkisuuspeli. Imagonrakennus politiikassa. Helsinki: WSOY.

van Zoonen, Liesbet (2003) "After Dallas and Dynasty we have... democracy". Articulating Soap, Politics and Gender. Teoksessa Corner, John \& Dick Pels (toim.) Media and the Restyling of Politics. Consumerism, Celebrity and Cynicism. London, Thousand Oaks \& New Delhi: Sage Publications, 99-116.

van Zoonen, Liesbet (2005) Entertaining the Citizen. When Politics and Popular Culture Converge. Lanman etc.: Rowman \& Littlefield Publishers.

Väisänen, Pekka (1992) Vallan varjossa: poliittisten toimittajien historiaa 1960-luvulta 1990-luvulle. Helsinki: Poliittiset toimittajat.

Westerståhl, Jörgen (1972) Objektiv nyhetsförmedling. Stockholm: Akademiförlaget.

Westerståhl, Jörgen (1983) Objective News Reporting: General Premises. Communication Research. 1983; 10: 403-424.

Wiio, Juhani (2006) Media uudistuvassa yhteiskunnassa. Sitra. http://www.sitra.fi/julkaisut/ Raportti65.pdf 